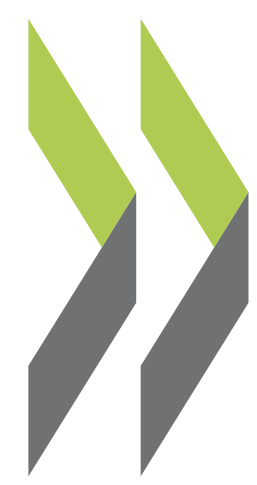

OECD Economics Department Working Papers No. 1547

Productivity growth and finance: The role of intangible assets a sector level analysis
Lilas Demmou,

Irina Stefanescu,

Axelle Arquie 


\section{By Lilas Demmou, Irina Stefanescu and Axelle Arquié}

OECD Working Papers should not be reported as representing the official views of the OECD or of its member countries. The opinions expressed and arguments employed are those of the author(s).

Authorised for publication by Luiz de Mello, Director, Policy Studies Branch, Economics Department.

All Economics Department Working Papers are available at www.oecd.org/eco/workingpapers.

JT03447469 
OECD Working Papers should not be reported as representing the official views of the OECD or of its member countries. The opinions expressed and arguments employed are those of the author(s).

Working Papers describe preliminary results or research in progress by the author(s) and are published to stimulate discussion on a broad range of issues on which the OECD works.

Comments on Working Papers are welcomed, and may be sent to OECD Economics Department, 2 rue André

Pascal, 75775 Paris Cedex 16, France, or by e-mail to eco.contact@oecd.org.

All Economics Department Working Papers are available at www.oecd.org/eco/workingpapers

This document and any map included herein are without prejudice to the status of or sovereignty over any territory, to the delimitation of international frontiers and boundaries and to the name of any territory, city or area.

The statistical data for Israel are supplied by and under the responsibility of the relevant Israeli authorities. The use of such data by the OECD is without prejudice to the status of the Golan Heights, East Jerusalem and Israeli settlements in the West Bank under the terms of international law.

(C) $\operatorname{OECD}(2019)$

You can copy, download or print OECD content for your own use, and you can include excerpts from OECD publications, databases and multimedia products in your own documents, presentations, blogs, websites and teaching materials, provided that suitable acknowledgment of OECD as source and copyright owner is given. All requests for commercial use and translation rights should be submitted to rights@,oecd.org 


\section{ABSTRACT/RÉSUME \\ Productivity growth and finance: The role of intangible assets A sector level analysis}

Investment in intangible assets has become an increasingly important driver of productivity growth in OECD countries. Facing stronger informational asymmetries and harder to value collateral, intangible investment is subject to more severe financial constraints and relies more on internal rather than external capital. To test the hypothesis that the availability of finance, and financial development in particular, is more important for productivity growth in sectors that are intensive in intangible assets, an empirical analysis is carried over a panel of 32 countries and 30 industries, from 1990 to 2014. Overall, results confirm that the impact of financial development on labour productivity is not uniform across sectors. It varies based on country-specific institutional settings and sector-specific characteristics such as the intangible asset intensity, financial structure and external financial dependence. Policies and institutional settings may relax financial constraints by: i) altering the overall composition of finance; ii) encouraging competition and iii) strengthening the legal environment in which businesses operate.

JEL Classification: G010, G210

Keywords: Intangible assets, Productivity Growth, Financial Development

\section{Croissance de la productivité et finance : Le rôle des actifs incorporels Une analyse sectorielle}

L'investissement en actifs incorporels est devenu un facteur de plus en plus important de la croissance de la productivité dans les pays de l'OCDE. Confrontés à des asymétries d'information plus fortes, à de plus grandes difficultés pour estimer leur valeur en tant que garantie d'emprunt, les investissements immatériels sont soumis à des contraintes financières plus sévères et reposent davantage sur des capitaux internes que externes. Pour tester l'hypothèse selon laquelle la disponibilité des financements, et le développement financier en particulier, est plus importante pour la croissance de la productivité dans les secteurs à forte intensité d'actifs incorporels, une analyse empirique est réalisée sur un panel de 32 pays et 30 industries, entre 1990 et 2014. Dans l'ensemble, les résultats confirment que l'impact du développement financier sur la productivité du travail n'est pas uniforme d'un secteur à l'autre. Elle varie en fonction des contextes institutionnels spécifiques à chaque pays et de caractéristiques sectorielles telles que l'intensité des actifs incorporels, la structure financière et la dépendance financière externe. Les politiques et les institutions peuvent assouplir les contraintes financières en: i) modifiant la composition générale du financement; ii) encourager la concurrence et iii) renforcer le cadre juridique dans lequel les entreprises évoluent.

Code de classification: G010, G210

Mots-clés: Actifs immatériels, croissance de la productivité, développement financier 


\section{Table of contents}

Productivity growth and finance: The role of intangible assets A sector level analysis................. 6

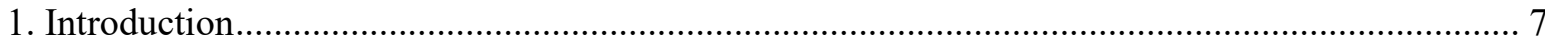

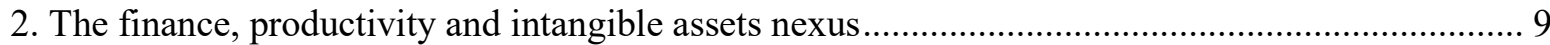

3. A new approach to evaluate the role of intangible intensity at industry level ............................. 12

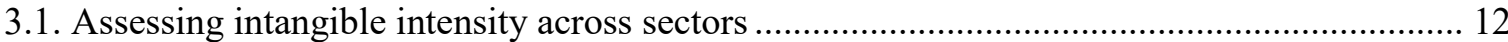

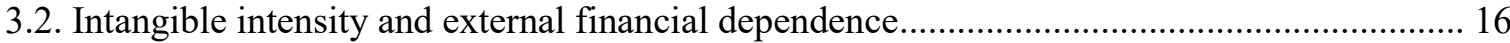

4. Linking finance, intangible intensity and productivity: empirical approach ............................... 18

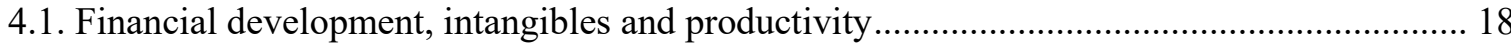

4.2. The role of the composition of finance, policies and framework conditions ........................... 20

4.3. Data on financial market development, institutions and policies.......................................... 21

5. Unlocking the growth potential of intangible assets through financial development .................... 23

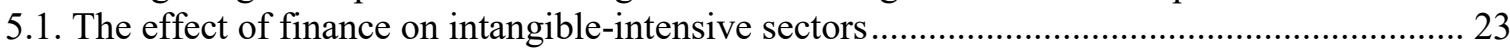

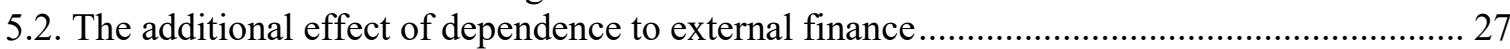

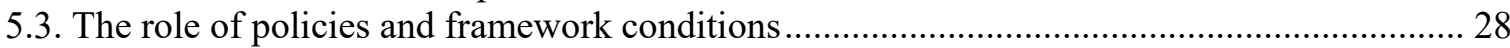

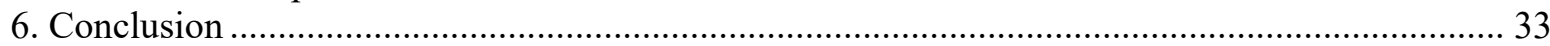

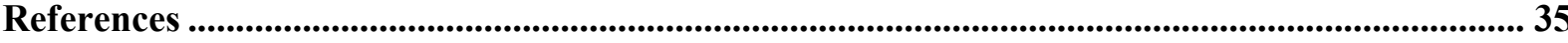

Glossary and Variable Definitions ............................................................................................................... 39

Annex A. Descriptive statistics and robustness checks ............................................................................ 41

\section{Tables}

Table 1. Description of financial development and policy variables ................................................. 22

Table 2. The links between financial development, intangible intensity and productivity ................... 25

Table 3. A collateral constraint reins in R\&D investment especially in intangible sectors and

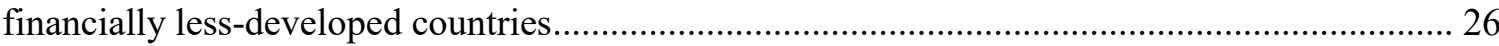

Table 4. The type of finance matters for productivity growth in intangible intensive sectors ............. 29

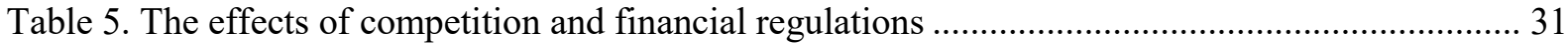

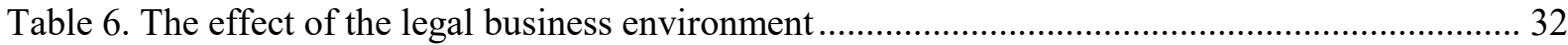

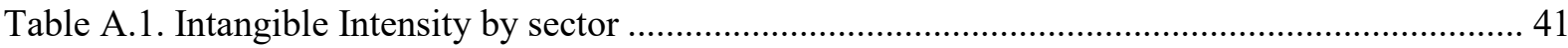

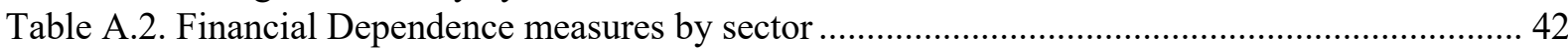

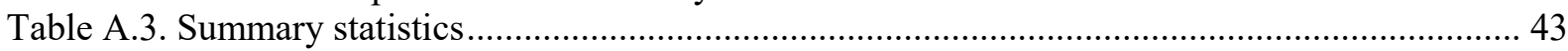

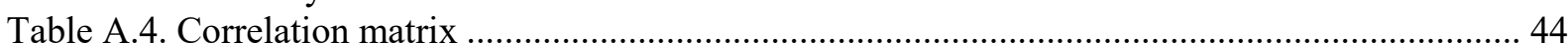

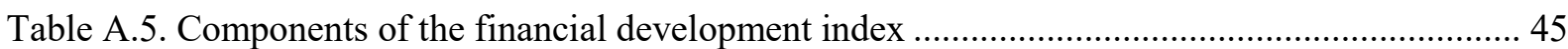

Table A.6. Robustness check: including additional country-year variables........................................ 45

Table A.7. Robustness check: including alternative fixed effects and clustering ............................... 46

\section{Figures}

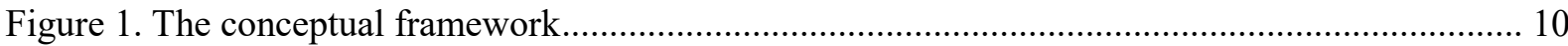

Figure 2. Average growth rate of tangible and intangible assets, 1995-2014 ..................................... 13

Figure 3. Investment in intangible assets across countries .............................................................. 14

Figure 4. Organisation- and knowledge- based intangible assets...................................................... 14 
Figure 5. Intangible versus tangible assets in the United States.... 16

Figure 6. Financial Dependence with and without intangibles....................................................... 17

Figure 7. External financial dependence and intangible asset intensity are independent phenomena .. 18

Figure 8 . The effects of financial development on productivity growth conditional on intangible intensity

Figure 9. The effects of financial development on productivity growth conditional on intangible intensity and external financial dependence.....

Figure 10. Economic significance of policy changes on relative productivity growth of intangibleintensive sectors

Figure A.1. External Financial Dependence and Intangible Assets Intensity over time 47

Figure A.2. Marginal Effect of Financial Development based on Equity Financial Dependence

\section{Boxes}

Box 1. Computing structural measures of intangible intensity and external financial dependence by sector

Box 2. Robustness checks

Box 3. Channels linking productivity and intangible assets intensity 


\title{
Productivity growth and finance: The role of intangible assets A sector level analysis
}

\author{
By Lilas Demmou, Irina Stefanescu and Axelle Arquié
}

\section{EXECUTIVE SUMMARY}

Investment in intangible assets has become an increasingly important driver of productivity growth in OECD countries. Facing stronger informational asymmetries and harder to value collateral, intangible investment is subject to more severe financial constraints and relies more on internal rather than external capital. To test the hypothesis that the availability of finance, and financial development in particular, is more important for productivity growth in sectors that are intensive in intangible assets, an empirical analysis is carried over a panel of 32 countries and 30 industries, from 1990 to 2014.

The overall level of financial development is measured by the size of the stock market and domestic credit relative to GDP as well as by more comprehensive indices, which combine the overall development of financial institutions and markets. The intangible intensity of an industry (defined as the ratio of intangible assets to total assets) is calculated based on U.S. data and includes an extensive range of intangible assets such as R\&D spending, new software, database, copyrights, designs, trademarks, and organisation and distribution networks.

Cross-country differences in financial development affect productivity growth across different sectors in different ways, depending on sector-specific characteristics (such as the intangible asset intensity, financial structure and external financial dependence) and country-specific institutional settings. Overall, policies and institutional settings may relax financial constraints linked to intangible assets by: i) altering the overall composition of finance; ii) encouraging competition and iii) strengthening the legal environment in which businesses operate.

- The composition of assets (tangible vs. intangible) is important when assessing the link between finance and productivity growth.

- Financial development increases productivity growth for intangible-intensive sectors.

- Policies aimed at promoting financial development are most effective at boosting productivity in sectors that have both high intangible intensity and high external finance dependence.

- Policies aimed at developing equity and venture capital markets, which are better suited for financing intangible intensive sectors can help fuel productivity growth in these sectors.

- Pro-competitive reforms in the banking sector aiming at reducing barriers to entry, decreasing the share of state-owned banks and removing interest rate controls can also help channelling resources to intangible intensive sectors, particularly in less financially developed countries.

- A strong legal business environment is particularly important in less financially developed countries. Easing insolvency procedures and strengthening contract enforcement can boost the productivity growth for intangible intensive sectors.

Reducing bank concentration while liberalising securities markets and improving transparency in credit worthiness is relatively more important in well-developed countries, improving financial markets' efficiency in allocating capital to intangible intensive firms.

${ }^{1}$ Lilas Demmou and Irina Stefanescu are members of the OECD Economics Department (Email: lilas.demmou@oecd.org; irina.stefanescu@oecd.org). Axelle Arquie is at CEPII, Paris, France (Email: axelle.arquie@cepii.fr). The authors would like to thank Luiz de Mello, Alain de Serres, Guido Franco, Peter Gal, Antoine Goujard, Valentine Millot, Giuseppe Nicoletti and Volker Ziemann, (all from the OECD Economics Department) as well as Luca Marcolin (from OECD Science, Technology and Innovation Directorate), Silvia Albrizio (Bank of Spain), delegates to the OECD Working Party 1 and seminar participants 


\section{Introduction}

1. Over the last two decades, intangible assets have grown in importance in many OECD economies and the growth rate of intangible investment has often surpassed that of tangible investment (Corrado and Hulten, 2010; Corrado et al., 2012, 2016). There has been growing recognition that besides R\&D activities, new software, database, copyrights, designs, trademarks, organisation and distribution networks are increasingly important for productivity growth. Overall, intangible assets have become a key component of the production function for many firms, a driver for innovation and growth. The unprecedented development of new technologies is increasingly perceived as the source of future growth and potentially a new engine to reverse the productivity slowdown observed in many OECD economies (Andrews et al, 2016).

2. However, intangible assets have been growing at different speeds in similar sectors across different countries, suggesting that these sectors have not fully reached their growth potential everywhere and some barriers may have curbed investment in intangible assets. In this context, an important question is whether policies and improvements in the quality of the institutional framework could help countries realise these growth opportunities.

3. This paper examines the role of financial development in general, and the role of policies and institutions in particular, in channelling finance to sectors that rely more on intangibles assets. The paper focuses on two related questions: i) Is financial development relatively more important for productivity growth in intangible intensive sectors? ii) For a given level of financial development, what are the policies or the institutional arrangements that could improve the efficiency in channelling finance to intangible intensive sectors?

4. The rationale behind examining the role of finance for intangible assets stems from the difficulty of pledging them as collateral. Intangible investments are typically riskier and the valuation of intangible assets is generally more volatile. Their liquidation value is more uncertain as they tend to be more firm specific and not easily transferable (e.g. human capital). Ensuring that the financial system is able to channel finance to these kinds of investments is hence a key challenge for policy makers.

5. To account for the rise of intangibles and their specific characteristics, this paper expands the traditional analytical framework linking finance and growth. A large body of literature links financial development to growth by showing that sectors that are more reliant on external capital are more sensitive to financial conditions (King and Levine, 1993; Rajan and Zingales 1998). However, most analyses ignore the specific constraints raised by intangible investment and thereby tend to underestimate the financial needs of firms undertaking such investment, which is generally connected to innovation.

6. This paper revisits the finance productivity nexus by exploring the ability of financial systems to finance a broad range of intangibles, going beyond the usual narrow focus on R\&D and patenting. Therefore, it adds to a body of research already undertaken at the OECD, which investigated the role of intangible assets for growth and innovation (OECD 2013), the link between resource allocation and intangible investment (Andrews and de Serres, 2012; Andrews and Criscuolo, 2013, Andrews et al., 2014) and the role of policies to support SMEs financing of intangibles (OECD, 2018). 
7. First, the paper examines the overall role played by financial development in unleashing the productivity potential of most intangible intensive sectors. Financial development is captured by a multidimensional variable comprising the supply of finance, the availability of banking services and their overall costs. Second, the paper explores how the interaction between two sector level characteristics, their intensity in intangible assets and their reliance on external finance, can influence the link between finance and productivity. Finally, the paper examines whether the relaxation of the collateral constraint is one of the potential channels linking financial development to productivity via intangible assets.

8. A wide range of policies and financing conditions affects the efficiency of financial system in each country. Therefore, in the next step, the paper examines the relevance of policies, particularly targeting three different areas: i) the composition of finance; ii) the level of competition and iii) the legal business environment. The paper provides evidence that the effect of financial development on productivity growth in intangible intensive sectors is more effective under certain financing arrangements, such as equity financing. Further evidence shows that financial development interacts with other country-specific features of financial systems, suggesting other possible country-specific alternatives that can help increase the productivity growth of these highly innovative sectors.

9. The main findings indicate that intangible intensive sectors experience higher labour productivity growth following policies and regulations that encourage:

- Financial development: Financial development is associated with stronger productivity growth in intangible intensive sectors. In terms of their economic significance, the main results suggest that a sector that has about $66 \%$ of assets in intangibles (such as Computer Equipment) experiences an annual labour productivity growth that is 1.2 percentage points larger in financially welldeveloped countries compared to the same sector in financially less-developed countries.

- More access to equity and venture capital: Estimates suggest that greater reliance on equity market than credit markets promotes growth in intangible intensive sectors as financial markets develop, perhaps reflecting the greater willingness of equity holders to finance long-term and risky investments even without strong collateral. The results are robust to narrowing the focus on the development of venture capital markets and looking at country-specific regulations on securities markets.

- Stronger competition in the banking sector, particularly in less financially developed countries: Pro-competitive reforms in the banking sector aiming at reducing barriers to entry and the share of state-owned banks tend to support productivity growth of the most intangible intensive sectors, more so in less financially developed countries. Removing controls on lending and deposit interest rates is equally important.

- Liberalised, open and stable financial markets, particularly in well financially developed countries: Bank concentration lowers the efficiency of financial markets to allocate capital to intangible-intensive firms, possibly because the lack of competition tends to favour incumbent and increases the cost of finance. Conversely, liberalised and open security markets to foreign investors supports productivity growth in the most innovative sectors. 
- Strong contract enforcement laws and more efficient insolvency regimes: Bankruptcy laws that do not penalise excessively failed entrepreneurs and a regulatory framework that ensures strong contract enforcement magnify the positive impact of financial development on productivity in intangible intensive sectors. This likely reflects enhanced incentives to invest in innovative activities, which are more likely subject to failures and to legal disputes regarding the appropriation of the returns from intellectual investment.

- Easy access to credit information: Policies that encourage the scope and the accessibility of credit information distributed by credit bureaus and credit registries boosts productivity in intangible intensive sectors of financially well-developed countries. Such credit transparency may be particularly useful for small firms to signal the quality of their business to investors.

10. The rest of the paper is organized as follows. First, we briefly present the conceptual framework underlying the analysis and the related literature. Second, we describe the data and the approach to define the industry-specific variables, the intangible assets intensity and the external finance dependence variables, used to identify the relative exposure of sectors to financial development. Third, the empirical approach is presented. Finally, we examine the empirical relationships between finance, intangible assets and productivity growth. The last section discusses the impact of policies and institutions.

\section{The finance, productivity and intangible assets nexus}

11. There is a wide consensus that intangible assets are a critical driver of labour productivity growth (see e.g. Andrews and de Serres, 2012; Andrews and Criscuolo, 2013, Corrado and Hulten, 2010). ${ }^{2}$ There is also a large body of literature linking financial development to growth by showing that sectors that are more reliant on external capital are more sensitive to financial conditions (King and Levine, 1993; Rajan and Zingales, 1998). However, less attention has been devoted to examine whether the relationship between finance and productivity growth is affected by the growing importance of intangible assets. The main objective of this paper is to provide a better understanding of these links (dotted area in Figure 1).

\footnotetext{
${ }^{2}$ Corrado and Hulten (2010) add intangible capital in a growth accounting framework and show that capital deepening becomes the main source of growth in the United States once accounting for intangible investment, while the role of TFP diminishes. Similar qualitative results have been found recently for European Union countries (Corrado et al., 2012; 2016).
} 
Figure 1. The conceptual framework

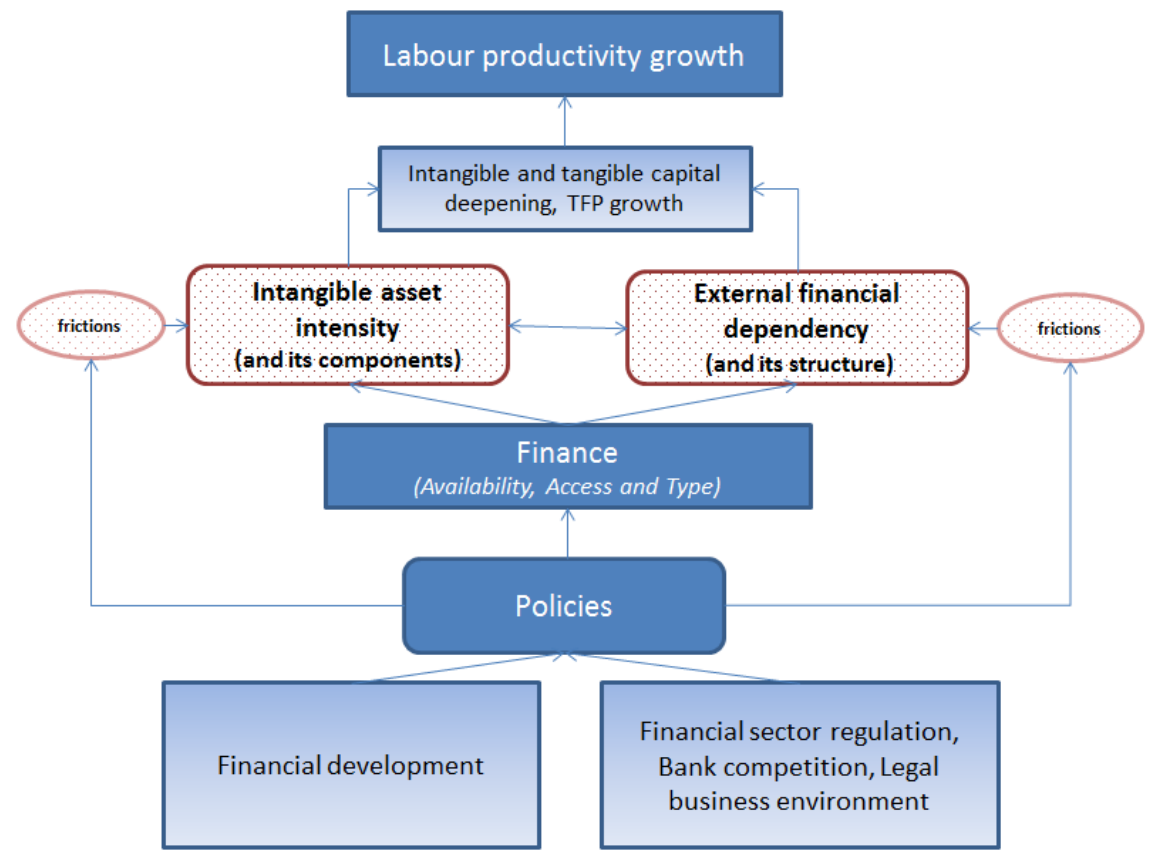

12. Given their characteristics, intangible assets are more difficult to finance compared to tangible assets and finance may therefore represent a severe obstacle for investment in these innovative activities. ${ }^{3}$ Asymmetry of information makes more difficult for external investors to evaluate the quality of projects and the risks of innovative investment making the return on innovative investment highly uncertain (Barth et al, 2001; Himmelberg and Petersen, 1994). Moreover, intangible assets offer little guarantee or collateral in the capital raising process. Human capital, organisational networks and brand value, for example, are more difficult to pledge. Being more specific to the firm, these assets have a significantly lower liquidation value, reducing the share debtors can capture in case of default and creating contracting problems (Hart and Moore, 1994). As a result, firms with relatively more intangible assets are more likely to face difficulties in raising capital (and obtaining loans), more likely to be financially constrained and less able to take advantage of investment opportunities (Almeida and Campello, 2007). The increasing size of intangible assets in OECD economies is therefore likely to amplify financial frictions and raises the importance of financial development.

13. The inherent difficulty to finance intangible assets combined with their strong productive capacity imply that the benefits arising from financial development are potentially stronger for sectors with relatively more intangible assets. For instance, relaxing financing constraints should have a higher impact on the investment into $R \& D$ (and other innovative activities) for these sectors. Recently, Hsu et al. (2014) and dell' Ariccia et al., (2017) provide evidence that financial development disproportionately supports innovation of high-tech sectors. Looking more specifically at the impact of financial frictions over the business cycle, Duval et al. (2017), Aghion et al. (2005) and Aghion et al. (2012a, 2012b)

\footnotetext{
${ }^{3}$ The paper focuses on financial frictions. Other specific characteristics of intangible assets that make market failures more severe are discussed for instance in OECD (2013).
} 
provide additional evidence that negative financial shocks hurt more strongly investment in R\&D.

14. The extent to which sectors rely on external finance may also shape the relationship between financial development and productivity growth of intangible-intensive sectors. Reliance on external finance exposes firms to a number of financial frictions, especially in less developed financial systems. These can affect tangible investment (Fazzari et al., 1988; Gilchrist and Himmelberg, 1995), for instance due to asymmetric information (Akerlof, 1970) or because of debt overhang (Myers, 1977).

15. Financial development can alleviate the frictions generated by external financial dependence by reducing the cost of credit and diversifying the sources of external funds available to firms. However, the standard measure of dependence on external finance has become an imperfect measure for the exposure to financial frictions, particularly for sectors intensive in intangible assets, as it relies mostly on tangible investments. The rise of intangible assets has also generated less overall reliance on external funds (Falato and Sim, 2013). ${ }^{4}$ Such evolution may explain why recent empirical research has failed to provide robust evidence that financially well-developed countries experience higher productivity growth in sectors dependent on external finance (Cecchetti and Kharroubi, 2015; Fisman and Love, 2004; Pagano and Pica, 2012; Gutierrez and Philippon, 2016).

16. The composition of finance also matters for productivity growth. Because of the longer term and riskier nature of intangible assets, market-based financing such as equity is more suitable than bank finance for financing their acquisition (for evidence on innovation, see Acharya and Xu, 2017; Hsu et al., 2014; Brown et al. 2009). Equity holders are generally long-term investors, willing to take risks, require no collateral and process information relatively more efficiently, while credit markets can limit loans when faced with strong asymmetric information due to adverse selection and moral hazard problems (Stiglitz and Weiss, 1981). By devoting resources to screening and monitoring of firms that otherwise cannot access capital markets (Hall and Lerner, 2009), venture capital plays a similar role in promoting innovation and patenting (Kortum and Lerner, 2001). As a result, countries with well-developed venture capital and equity markets should grow faster, and particularly so in intangible-intensive sectors.

17. Finally, policies and institutional settings (i.e. financial market regulation and the legal business environment) have an additional impact on the cost and availability of finance, shaping once more the way financial development impacts productivity growth of intangible sectors (bottom part of Figure 1). Policy reforms can encourage, support or act synergistically with financial development. For instance, for a similar level of financial development and similar cost of external capital, the country-specific legal business environment may shape the incentives to undertake (risky) investment.

18. Four broad policy areas are considered to affect investment in intangibles in this paper:

- Regulations that affect entry and competition in the banking and financial system. Lifting barriers to entry and increasing competition can lead to more credit, lower interest rates, more efficient banking services and better products (Claessen and Leaven, 2005; Bai et al, 2017). Easier access to banking and finance can also lower

\footnotetext{
${ }^{4}$ Falato and Sim (2013) have shown that the rise of intangible assets has been the most important driver of corporate cash holding in the United States and Peters and Taylor (2017) estimate that less than $20 \%$ of firms' intangibles are purchased externally.
} 
resource misallocation and strengthen the financing of best performing firms (Andrews and de Serres, 2012) and more generally is associated with higher productivity growth of innovative sectors (Benfratello, et al., 2008; Chava et al., 2013; Cornaggia et al., 2015). However, regulation also plays a role for ensuring the stability of the financial sector, underpining long-term growth (Caldera Sanchez et al., 2017). A critical challenge is therefore to establish policies that provide the right balance between preserving the stability of the banking system and fostering its efficiency.

- Transparency of credit information. Making credit reporting on borrowers available from credit registries and bureaus contributes to reduce the asymmetry of information between creditors and borrowers and is generally associated with a better access to credit for firms, lower interest rate and improved repayment discipline from borrowers (World Bank, 2018). Transparency of information tends to particularly beneficial for financially constrained small and young firms that are not externally audited and lack of quality certification (Chávez and Ivan, 2017). As the level of information asymmetry is increasing with the intangible intensity of firm, such reporting could arguably help small firms (with already a credit record) to access external capital.

- The legal enforcement of contracts. Innovative ideas are more likely to materialize into a business plan when the institutional framework provides appropriate legal protection to innovators (Claessen and Laven, 2003). Strong legal enforcement of contracts provides more incentives to undertake intangible investment as it allows securing returns on assets, which are harder to achieve for intangibles than tangibles.

- Insolvency regimes. Undertaking risky investment depends on the balance between anticipated benefits and the expected costs in case of failure (Andrews and Criscuolo, 2013). Legally protecting entrepreneurs against creditors in case of failure is an important driver of business dynamism (la Porta et al., 1998). Establishing balanced insolvency regimes that protect creditors but also reduce barriers to corporate restructuring and personal costs associated with entrepreneurial failure is supportive of an efficient reallocation process. Easing bankruptcy procedure allows resources to flow from the less successful firms to the most productive firms and successful innovators (OECD, 2013; Calvino et al., 2016). It provides also more incentive to move to new ideas in case of failure and strengthen incentives to undertake radical innovation compared to incremental innovation (Bartelsman et.al., 2004; OECD, 2013).

\section{A new approach to evaluate the role of intangible intensity at industry level}

19. The key conjecture in this paper is that financial development helps overcome financial frictions that affect productivity by bridling investment, and that the sector dependence on external finance and intangible intensity can capture the extent to which different industries are sensitive to these frictions.

\subsection{Assessing intangible intensity across sectors}

20. Aside from investments in $R \& D$, patents and software which have been for a long time perceived as key intangible investments, other types of assets -- such as databases, copyrights, designs, trademarks, organisation and distribution networks -- have become 
important for productivity growth (Andrews and de Serres, 2012; Marrocu et al., 2012). Moreover, these assets affect productivity in a complementary way, since for instance the impact of R\&D investment depends on the ability of the firm to invest in other intangibles such as managerial skills, network building or upgrading organisational capabilities (Bloom et al., 2012; Andrews et al., 2018; McAfee and Brynjolfsson, 2012).

21. Broad measures of intangible capital at the macroeconomic level show that intangible assets have been growing at fast rates in all OECD economies (Corrado et al., 2010, 2012, 2016), in some cases even faster than tangible capital (Figure 2). However, international comparisons also reveal significant cross-country differences in the stock of intangibles and in their composition (Figure 3). Part of these differences depends on sectoral specialization (and the related economy-wide scope for intangible investment) rather than on financing constraints. To identify the specific role played by such constraints and their linkage to policies it is important therefore to estimate a measure of intangible intensity that captures the potential for such investment in each sector.

Figure 2. Average growth rate of tangible and intangible assets, 1995-2014

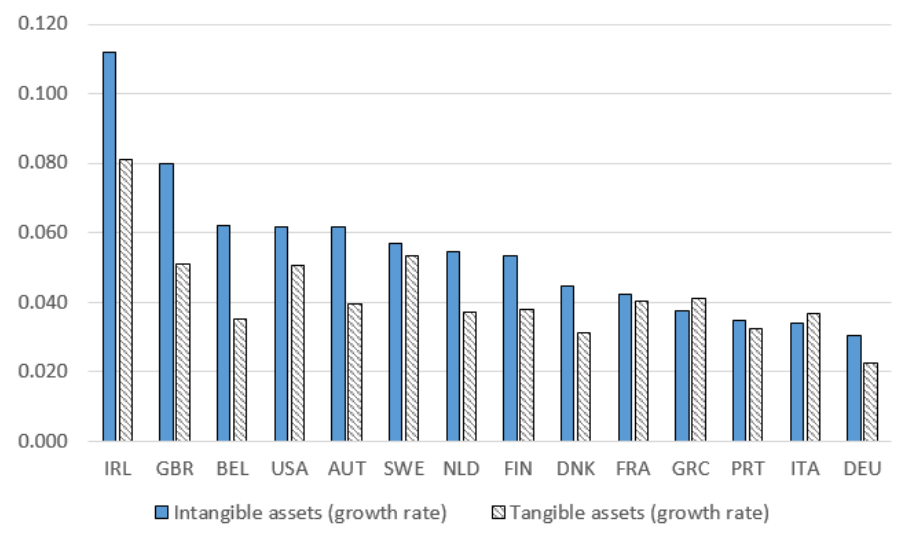

Note: The figure shows the average of the yearly growth rates in either the stock of intangible capital (blue bars) or the stock of tangible capital (dashed bars) for selected OECD countries during the 1995-2014 period (the only exceptions are Italy and Portugal, for which we evaluate the 2000-2014 period, due to limited data availability in earlier years). The stock of intangible assets is calculated as in Corrado et al. (2016).

Source: IntanInvest project; OECD National Accounts Database.

22. To this end, a sectoral measure of intangible intensity is calculated based on U.S. listed firms over the period 1990-2006 (Box 1). The implicit assumption is that these firms benefited from relatively less restricted access to finance during the pre-crisis period. Therefore, their observed intangible intensity in each sector reflects the desired balance between tangible and intangible capital resulting solely from technological characteristics (related for instance to the length of the investment projects, the period over which cash collection is expected and risks). A further assumption is that these technological characteristics of sectors in the U.S carry over to the same sectors in other countries.

23. The resulting share of intangible assets is sizeable in most sectors, but there is also substantial variation, with the highest intangible intensity reaching over 70 percent in Programming and Information and Pharmaceuticals, and intangible intensity being the lowest in Basic Metals, Mining and Transport. Wide differences emerge also on the relative importance of knowledge and organisational capital (Figure 4), suggesting that exposure to financial frictions may differ even across sectors with similar overall intangible intensity depending on its composition. 
Figure 3. Investment in intangible assets across countries

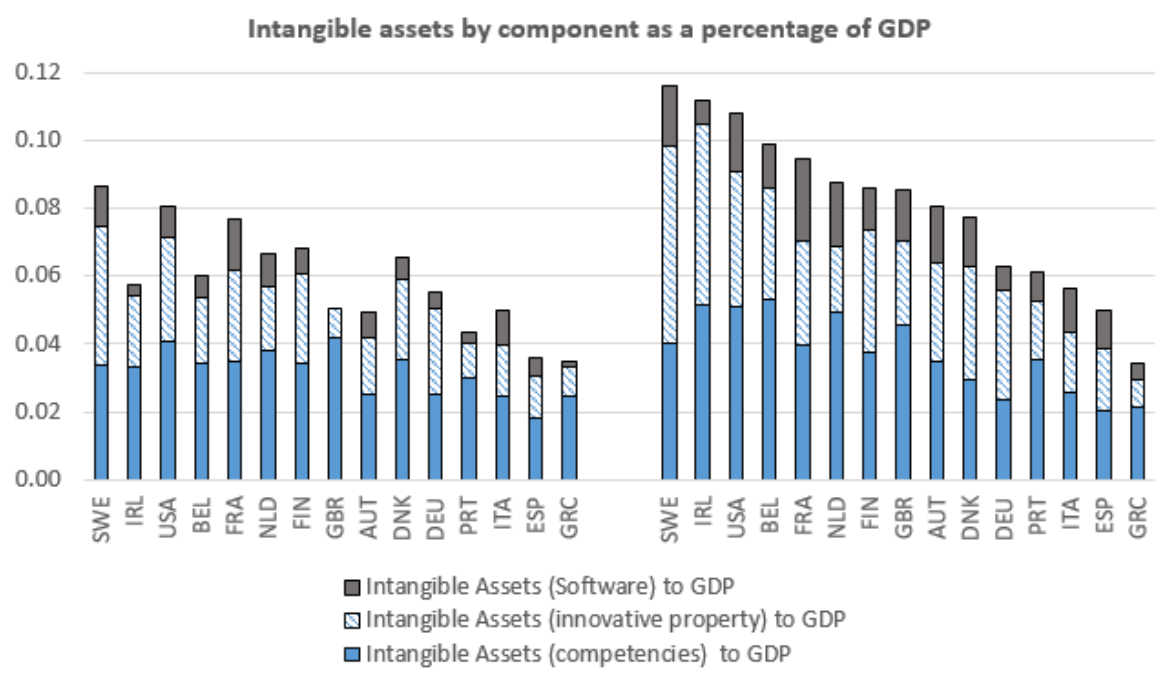

Note: This figure shows the rise in the stock of intangible assets as a share of GDP by comparing the intangibles to GDP ratio in 1995 (the only exception is Portugal, for which we use 2000, the first available date) and 2014 in a sample of OECD countries. Intangible assets are calculated as in Corrado et al. (2016).

Source: IntanInvest, OECD National Accounts Database.

Figure 4. Organisation- and knowledge- based intangible assets

Manufacturing

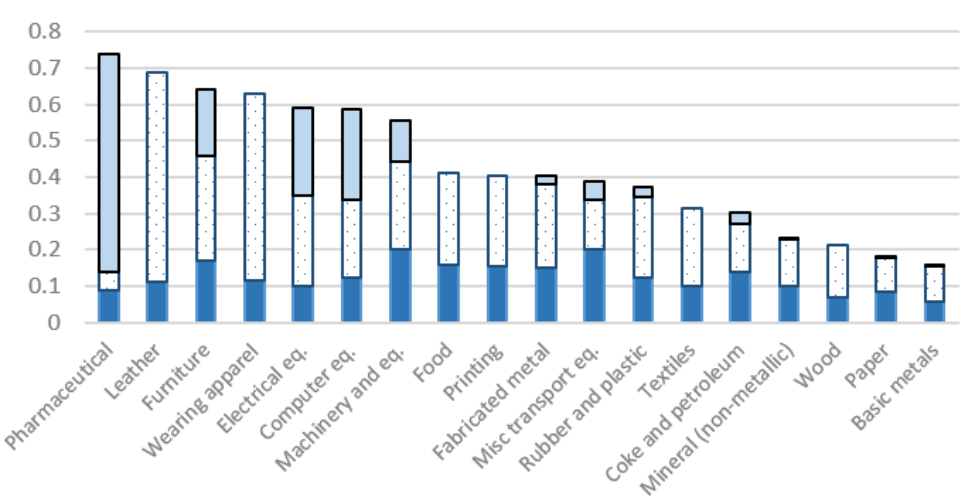

口Knowledge-based intangible assets as a ratio of total assets

Organization-based Intangible assets as a ratio of total assets

Intangible assets recognized on balance sheet as a ratio of total assets

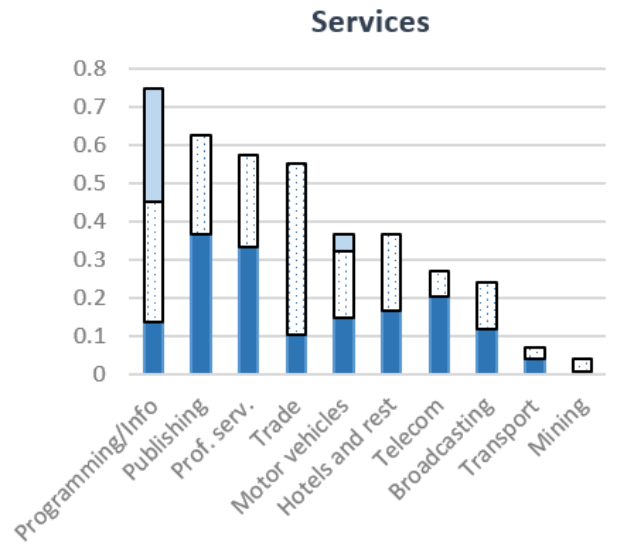

Services

Note: Intangible asset intensity is defined as the median sector-level value of the ratio between intangible assets and total assets. It is calculated for all U.S. listed firms in Compustat from 1990-2006, excluding financial, utilities and public service. Intangible assets off the balance sheet are differentiated into knowledge- and organisation- based assets, based on the type of expenses that are capitalized (see Box 1 for more details).

Source: Compustat. 


\section{Box 1. Computing structural measures of intangible intensity and external financial dependence by sector}

Measures of intangible intensity and financial dependence by sector are calculated at firm level using U.S. data from 1990 to 2006, based on the cumulative amounts of intangible investment and external finance over the period in order to avoid lumpy variations during any particular year. Then firm-level data are collapsed at the industry median level. Utilities, financial firms and firms categorized as public service are excluded. To avoid the contamination of these measures by the crisis all years after the financial crisis are also excluded from these calculations

\section{Intangible intensity}

Intangible intensity is defined as the ratio of intangible assets to total assets (tangible and intangible). The measure of intangible capital builds on the work of Peters and Taylor (2017). Similar methodologies are used by Eisfeldt and Dimitris (2013), Eisfeldt and Papanikolaou (2014), Falato et al. (2013), Lev and Radhakrishnan (2005).

The source of firm-level data is Compustat. Intangible assets are calculated as the sum between externally purchased and internally created intangible capital. According to the U.S accounting standards, the externally and internally created intangible capital are subject to different rules.

Intangible assets that are purchased externally (patents or through a firm acquisition) are included on balance sheet as part of intangible assets (Compustat item intan). These intangible assets are further separated based on whether assets are directly identifiable (such as a patents) in which case they are booked under Other Intangible Assets. If not identifiable, they are classified as Goodwill.

Intangible assets that are created internally are expensed on the income statement and almost never appear as assets on the balance sheet. The balance sheet item includes however a few small exceptions when the internally created intangibles are capitalized on balance sheet (ex. legal costs, consulting fees, registration fees incurred in developing a patent or trademark). Peters and Taylor (2017) strategy to estimate internal intangible capital consists in capitalizing intangible investments as reported in income statements.

Intangible capital can be further classified in knowledge- or organisation- based capital based on the type of expenses that are capitalized. Knowledge-based capital includes a firm's spending to develop knowledge, patents, or software while the organisation-based is computed by using a fraction of the Selling, General and Administrative expense (SG\&A), which includes advertising to build brand capital, human capital, customer relationships and distribution systems (see Table A.1).

Results show that the importance of intangible assets in the United-States has grown over time, with the ratio of intangible assets to total assets coming closer to that of the tangible capital stock in 2006 (Figure 5). Importantly, intangible assets that are not yet recognized on balance sheets have grown over time confirming that disregarding those assets may underestimate the importance of intangible assets in the economy.

\section{External financial dependence}

The standard measure of external financial dependence is computed as the ratio of the difference between cumulative capital expenditure and cumulative cash flow operations to cumulative capital expenditures. Since this measure presumes that only tangible assets need financing from external sources, it is expanded in this paper to include R\&D as part of investment, in both the numerator and denominator. ${ }^{5}$

The standard measure of financial dependence is further refined by looking at external equity dependence which is calculated as the ratio of the net amount of equity issues to tangible and R\&D investment (in line with the definition of financial dependence). 
Figure 5. Intangible versus tangible assets in the United States
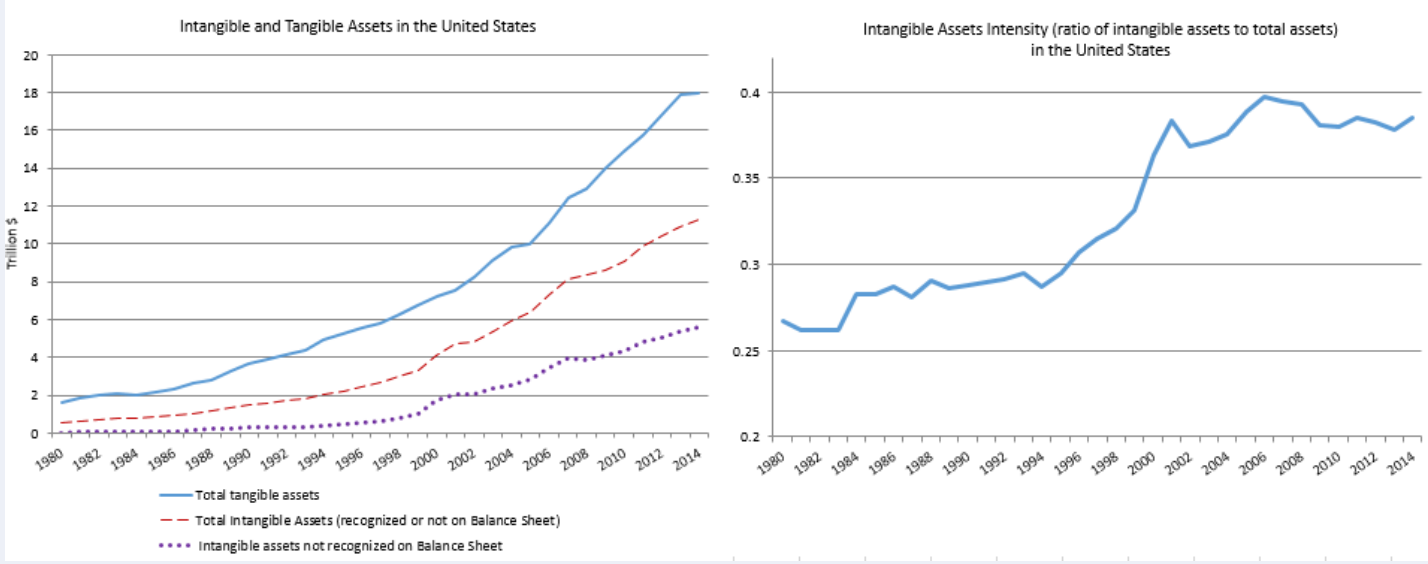

Note: Intangible assets are estimated based on the methodology described in Peters and Taylor (2017). Tangible capital stock is defined as the cumulative investment in plant and equipment. The dotted line shows the level of intangibles that is not recognized on balance sheet according to the U.S. accounting standards. Intangible asset intensity is defined as the median sector-level value of the ratio between intangible assets and total assets. It is calculated for all U.S. listed firms in Compustat from 1990-2006, excluding financial, utilities and public service.

Source: Compustat.

\subsection{Intangible intensity and external financial dependence}

24. Reliance on external finance is another indicator of potential exposure to financial frictions. Following Rajan and Zingales (1998) this paper defines the external financial dependence ratio as the percentage of investment financed externally. As with intangible intensity, this ratio is calculated using data on U.S. listed firms under the assumption that these firms had reached their desired capital intensity during the pre-crisis period (see Box 1), thus capturing a structural characteristic of the sector. While the Rajan-Zingales approach considered only spending on tangible capital, the rise in intangible assets requires a refinement of the standard calculation to account for the accumulation of these assets. Therefore, a new measure of financial dependence is computed recognising that intangible investment also requires external funding. Indeed, taking into account $R \& D$ spending increases the dependence on external finance in some sectors (see Figure 6 and Table A.1).

\footnotetext{
${ }^{5}$ An alternative proxy of external finance dependence is computed, which incorporates all intangible capital investment in both the numerator and denominator. It leads to a rescaled measure of financial dependence that includes $R \& D$, as SG\&A expenses are already included in the calculation of operating cash flows. For this reason, and for a much simpler comparison of our results with previous research, the paper focuses on the measure including only R\&D (See Table A.2).
} 
Figure 6. Financial Dependence with and without intangibles

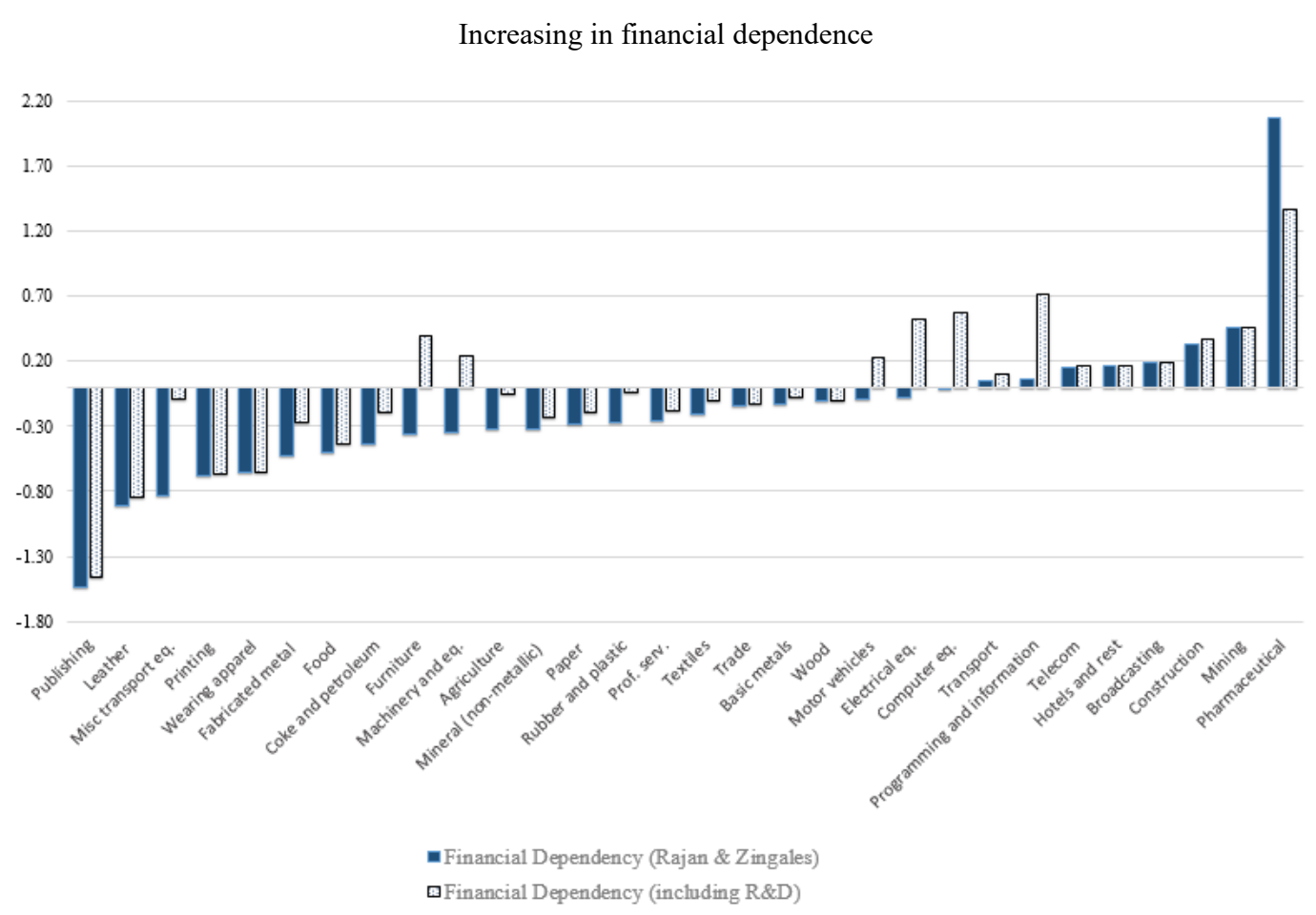

Note: External financial dependence is calculated as in Rajan and Zingales (1998), extended over 1990-2006. External financial dependence (including R\&D) is the external financial dependence that includes R\&D expenditures. It is defined as the ratio between cumulative capital expenditures (including R\&D) minus cumulative cash flow from operations and cumulative capital expenditures calculated at firm level from 1980 to 2006. For more details see Box 1. The sample includes all U.S firms in Compustat, excluding financial, utilities and public service.

Source: Compustat

25. The proxies for intangible intensity and external financial dependence based on US firm-level data are both relatively stable over time and mutually uncorrelated, suggesting that they measure independent structural characteristics of sectors. The correlation of the measures over time (between 1995 and 2005) is high: it is estimated at $85 \%$ for the external financial dependence measure and at $95 \%$ for the intangible intensity index. The level of sectoral financial dependence has varied over time for some sectors, but the relative ranking of sectors along the financial dependence dimension appears broadly persistent. At the same time, both the ranking and the level of intangible intensity appear to be time invariant (Figure A.1). Moreover, intangible-intensive sectors can be both externally and internally financial dependent (Figure 7). Some industries, and in particular those that rely more on organisational capital (such as distribution networks) and less on long term investments (such as research and development), are more likely to harvest cash on their investments more quickly and thus have a lower demand for external capital. The lack of correlation between the two measures suggests that they capture different sector characteristics, which once combined could affect in a non-linear way the impact of financial development on productivity growth. 
Figure 7. External financial dependence and intangible asset intensity are independent phenomena

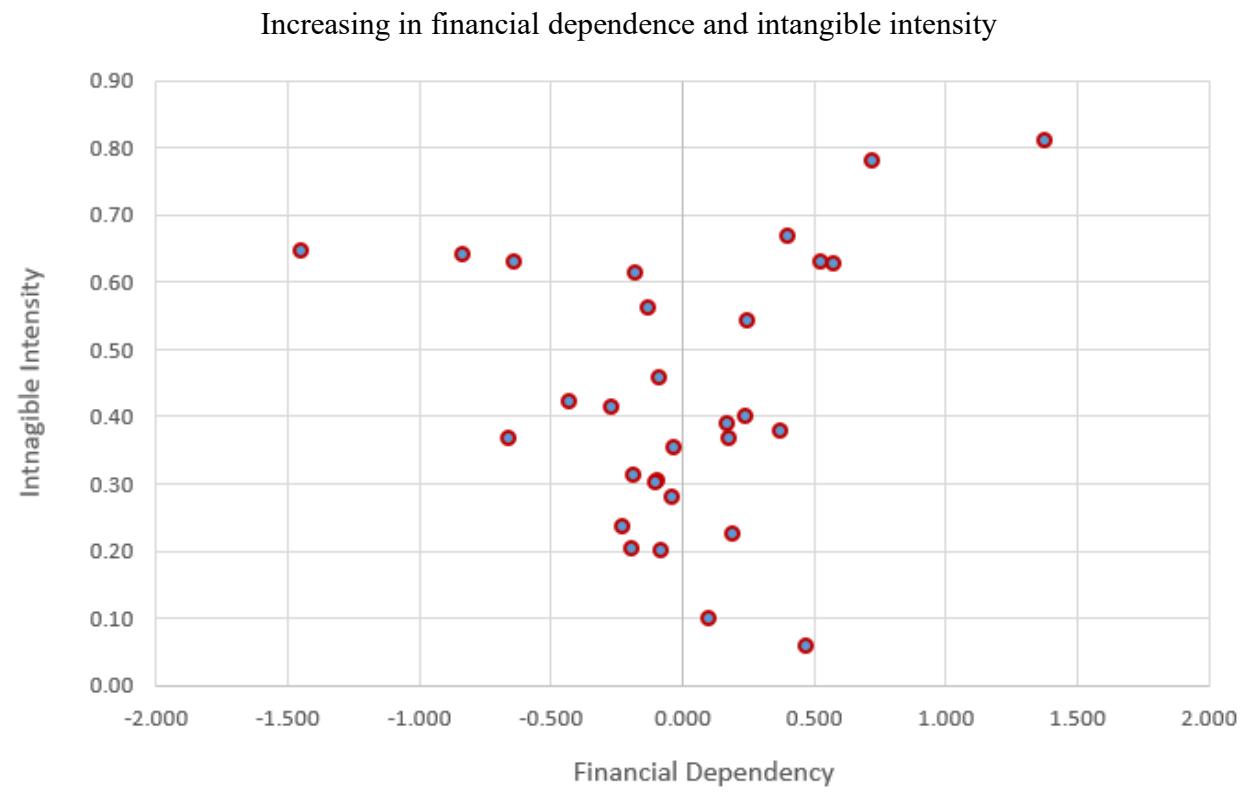

Note: Financial dependence is the ratio between cumulative capital expenditures (and R\&D) minus cumulative cash flow from operations and cumulative capital expenditures (and R\&D) calculated as firm level from 1990 to 2006. Intangible asset intensity is defined as the median sector-level value of the ratio between intangible assets and total assets. It is calculated for all U.S. listed firms in Compustat from 1990-2006, excluding financial, utilities and public service.

Source: Compustat.

\section{Linking finance, intangible intensity and productivity: empirical approach}

26. To identify the impact of financial development on productivity, this paper uses an identification strategy that is similar to Rajan and Zingales (1998). The paper exploits crosssector differences in intangible intensity (and external financial dependence) to capture the exposure of each industry to financial constraints. These variables are then interacted with country-level measures of financial development and policies to further investigate whether labour productivity growth of intangible-intensive (and financial dependent) sectors is relatively more affected by financial development.

\subsection{Financial development, intangibles and productivity}

27. To test whether the impact of financial development on labour productivity varies based on the intangible intensity of the sector, the following regression is estimated:

$$
\begin{gathered}
\Delta \log L P_{c, j, t+1}=\beta_{0}+\beta_{1}\left(\text { FinDEV }_{c, t} \times \text { IntangIntens }_{j}\right)+\beta_{2} \log L P_{c, j}+\beta_{3} \Delta \log K_{c, j, t} \\
+\eta_{c, t}+\mu_{j}+\varepsilon_{c, j, t+1}
\end{gathered}
$$

where $\mathrm{c}, \mathrm{j}$ and $\mathrm{t}$ refer to the three dimensions of our panel: country, industry and year. $\Delta \operatorname{logLP}$ refers to the change of $\log$ labour productivity, $\log \Delta \mathrm{K}$ refers to the change of $\log$ capital stock, FinDEV refers to the IMF financial development index (described below), IntangIntens refers to the intangible asset intensity of the sector, and $\operatorname{logLP}$ refers to the 
initial level of log labour productivity to control for catching-up effects. $\eta_{\mathrm{c}, \mathrm{t}}$ are countryyear fixed effects and control for shocks specific to a country in a given year (such as economic cycle, government policies and country-wide reforms). $\mu_{\mathrm{j}}$ are industry fixed effects and control for unobservable industry invariant characteristics that are common to all countries. We cluster standard errors by industry to correct for the fact that productivity growth may be systematically correlated within sectors. ${ }^{6}$ Country-sector heterogeneity is captured in this specification by the initial level of labour productivity and in further robustness analyses by interacting country time varying macro variables with the sector level intangible assets intensity. The risk of reverse causality is reduced by calculating intangible intensity and external financial dependence based on U.S firm-level data from 1990 to 2006.

28. While the inclusion of country-time fixed effect improves the identification strategy, it also implies that the average effect of financial development on productivity will be absorbed by country-year fixed effects. The analysis of the baseline model focuses therefore on the sign and significance of $\beta_{1}$, the interaction term coefficient. A positive and significant coefficient would suggest that financial development plays a more important role in relaxing financial constraints for most intangible-intensive sectors. More specifically, it suggests that the more financially developed the country, the higher labour productivity growth in intangible-intensive sectors relative to other sectors in this country. The analysis is further refined by separately looking at the knowledge- and organisationbased components of intangible capital to identify the type of intangible assets that are more sensitive to financial constraints. Additionally, the baseline regression is extended to test whether the results are robust to the inclusion of additional macro country-level variables that could affect labour productivity through the intangible intensity channel (Box 2).

29. As discussed above (sections 2 and 3), the impact of financial development on the productivity of intangible intensive sectors may also depend on the extent to which they rely on external finance. To test the additional effect of dependence to external finance on the relationships between finance, productivity and intangible assets, the baseline model is extended to include a triple interaction:

$$
\begin{gathered}
\Delta \log L P_{c, j, t+1}=\beta_{0}+\beta_{1}\left(\text { FinDEV }_{c, t} \times \text { IntangIntens }_{j}\right)+\beta_{2}\left(\text { FinDEV }_{c, t} \times \text { FinDEP }_{j}\right) \\
+\beta_{3}\left(\text { FinDEV }_{c, t} \times \text { IntangIntens }_{j} \times F i n D E P_{j}\right)+\beta_{4} \log L P_{c, j}+\beta_{5} \Delta \log K_{c, j, t}+\eta_{c, t}+\mu_{j}+\varepsilon_{c, j, t+1}
\end{gathered}
$$

30. The inclusion of the triple interaction term makes the interpretation of the results more difficult, as the effect of financial development is now conditional on both the level of external financial dependence and the level of intangible intensity. This effect depends on the combination of the estimated coefficients $\beta_{1}, \beta_{2}$, and $\beta_{3}$, their variances and the values at which IntangIntens and FinDEP are estimated (Braumoeller, 2004). Hence, we calculate and report graphically the marginal effect of financial development on labour productivity growth at different levels of the intangible intensity and different degrees of external financial dependence based on the following equation:

\footnotetext{
${ }^{6}$ Alternative fixed-effects and clustering specifications are presented in the Appendix. For example, including country-year and country-sector fixed effects does not significantly change the results.
} 


$$
\frac{\partial\left(\Delta \log L P_{c, j, t+1}\right)}{\partial\left(\operatorname{FinDEV}_{c, t}\right)}=\beta_{1} \text { IntangIntens }_{j}+\beta_{2} \text { FinDEP }_{j}+\beta_{3}\left(\text { IntangIntens }_{j} * \text { FinDEP } P_{j}\right)
$$

31. The economic question asked is whether external financial dependence amplifies even further the exposure to financial frictions. For an easier interpretation of the results, the external financial dependence variable is transformed into a categorical variable $\mathrm{dFinDEP}$ taking value 1 for industries that are dependent on external finance (positive financial dependence) and 0 for industries that are not (negative financial dependence). In this framework, the effect of financial development on labour productivity, conditional on intangible intensity, is captured by $\beta_{1}$ for low financial dependence sectors and approximated by $\beta_{1}+\beta_{3}$ for high financial dependence sectors. ${ }^{7}$

\section{Box 2. Robustness checks}

Omitted macro variables correlated with the measures for financial development could potentially bias the estimates if fast growing countries experience high productivity growth through the intangible intensity channel that is unrelated to financial development. In robustness checks, the baseline regressions are therefore extended by including additional macro countrylevel variables interacted with the intangible intensity variable. The interaction coefficient between financial development and intangible assets intensity should become insignificant if results of the baseline model were driven by such omitted variable bias. Variables considered for the extension are GDP growth, inflation and labour market restrictiveness:

- GDP growth captures new investment opportunities which are potentially stronger in intangible-intensive sectors and is highly correlated with financial development (King and Levine, 1993).

- Inflation can lead to lower productivity growth through misallocation of resources (Frenkel and Mehrez, 2000) and intangible-intensive sectors, where the information asymmetry is more severe, could suffer the most. Inflation is correlated to financial development, notably through monetary policy and the availability of credit.

- Excessively restrictive labour regulations can affect sectoral productivity if they lead to labour market rigidities and skills mismatches (Bassanini et al.,2009). The effect can be stronger for more intangible-intensive sectors, which depend more on human capital.

\subsection{The role of the composition of finance, policies and framework conditions}

\subsubsection{Composition of finance}

32. To identify the effect of the composition of finance on productivity growth of intangible-intensive sectors, two approaches are adopted:

- A variant of equation (1) is estimated replacing the variable for financial development by a country-level variable capturing either the size of venture capital

\footnotetext{
${ }^{7}$ The sum of $\beta_{1}+\beta_{3}$ is the second derivative of LP growth with respect IntangIntens in equation 3. It indicates the slope of the global effect of financial development, which is a close approximation of the effect of financial development on labour productivity growth, conditional on the level of intangible assets intensity for sectors that depend on external finance.
} 
or the size of the private equity market. This allows to directly estimate the contribution of those suppliers of funds to productivity growth.

- A variant of equation (2) is estimated using only the component of external financial dependence measuring financial dependence on equity (see Box 1). By incorporating information on the type of investor prevalent in each sector, the external equity dependence variable captures another structural feature of sectors that relates to the typical length and risk of investment. A positive coefficient for the interacted term is interpreted as indirect evidence that the effect of financial development on productivity growth operates via the development of equity markets.

\subsubsection{Policies and framework conditions}

33. To test the additional effect of policies and framework conditions, on the ability of the financial system to support growth of the most innovative sectors, a variant of equation 2 above is estimated:

$$
\begin{gathered}
\Delta \log L P_{c, j, t+1}=\beta_{0}+\beta_{1}\left(\text { IntangIntens }_{j} \times \text { Pol }_{c, t}\right)+\beta_{2}\left(\text { IntangIntens }_{j} \times \text { FinDEV }_{c, t}\right) \\
+\beta_{3}\left(\text { IntangIntens }_{j} \times \text { Pol }_{c, t} \times \text { FinDEV }_{c, t}\right)+\beta_{4} \log L P_{c, j}+\beta_{5} \Delta \log K_{c, j, t}+\eta_{c, t}+\mu_{j}+\varepsilon_{c, j, t+1}
\end{gathered}
$$

34. The variable Pol refers alternatively to direct regulatory measures and a set of outcomes variables aimed at capturing framework conditions (see below). The underlying idea is to assess the additional effect of specific regulations for a given level of financial development (well versus less financially developed countries). Again, for an easier interpretation of the results, the financial development variable is transformed into a categorical variable $d F i n D E V$ equal to $l$ for above median values and 0 otherwise. This transformation also alleviates problems related to collinearity that may exist between the regulatory variables considered and our variable for financial development (Table A.4). The marginal effect of policies conditional on the level of intangible intensity for financially less- and well-developed countries is captured by $\beta_{1}$ and $\beta_{1}+\beta_{3}$, respectively.

\subsection{Data on financial market development, institutions and policies}

35. Besides the measures of intangible intensity and external financial dependence described in the previous section, the empirical analysis relies on sectoral data on output per worker and capital stocks (both computed from the OECD STAN database) and the following financial market indicators: i) outcomes variables measuring finance availability and framework conditions; and ii) regulatory variables measuring more directly the impact of policies (Table 1). ${ }^{8}$ Our final panel is defined at country-sector-year level, and is slightly unbalanced. Overall, the analysis covers a panel of 32 economies and 30 industries over the period 1990 to 2014 .

\footnotetext{
${ }^{8}$ Summary statistics for these variables are described in Table A.3.
} 
Table 1. Description of financial development and policy variables

\begin{tabular}{|c|c|c|}
\hline & Source & Description \\
\hline \multicolumn{3}{|l|}{ Outcome variables } \\
\hline $\begin{array}{l}\text { Financial Development } \\
\text { Index }\end{array}$ & IMF & $\begin{array}{l}\text { It consists of nine indices which capture the overall financial condition, integrating measures } \\
\text { for the supply of finance (from banks and financial markets), the number of banks and the } \\
\text { costs of financial services. The index and subindexes go from } 0 \text { to } 1 \text {. }\end{array}$ \\
\hline $\begin{array}{l}\text { Financial Institution } \\
\text { development Index }\end{array}$ & IMF & $\begin{array}{l}\text { It consists in three indices for depth (volume of bank credits and assets from other financial } \\
\text { institutions), access (number of branches and ATM) and efficiency (proxied by different } \\
\text { measures of profitability). }\end{array}$ \\
\hline $\begin{array}{l}\text { Financial Market } \\
\text { development Index }\end{array}$ & IMF & $\begin{array}{l}\text { It consists in three indices for depth (stock market capitalisation and debt securities), access } \\
\text { (share of market capitalisation outside } 10 \text { largest companies) and efficiency (proxied by stock } \\
\text { market turnover ratio). }\end{array}$ \\
\hline Size of credit & & Private credit divided by GDP \\
\hline Market capitalisation & & Stock market capitalisation divided by GDP \\
\hline $\begin{array}{l}\text { Venture Capital and private } \\
\text { equity }\end{array}$ & Eurostat & $\begin{array}{l}\text { Venture capital relative to GDP (a subset of private equity) refers to equity investment made } \\
\text { in early, maturity and buyout stage of business developed by enterprises not quoted on the } \\
\text { stock market. }\end{array}$ \\
\hline Bank concentration & World Bank & $\begin{array}{l}\| \text { measures the assets of three largest commercial banks as a share of total commercial } \\
\text { banking assets }\end{array}$ \\
\hline \multicolumn{3}{|c|}{ Regulatory and policy variables } \\
\hline $\begin{array}{l}\text { Banking and financial } \\
\text { system regulatory index }\end{array}$ & $\begin{array}{l}\text { OECD (Denk and Gomez, } \\
\text { 2017) }\end{array}$ & $\begin{array}{l}\text { The index characterizes the regulation of the financial sector along seven dimensions: credit } \\
\text { controls; interest rate controls; banking sector entry barriers; capital account controls; state } \\
\text { ownership of banks; regulation of securities markets; and prudential regulation and bank } \\
\text { supervision. The index goes from } 0 \text { to } 1 \text {. }\end{array}$ \\
\hline $\begin{array}{l}\text { Regulation of securities } \\
\text { market }\end{array}$ & $\begin{array}{l}\text { OECD (Denk and Gomez, } \\
\text { 2017) }\end{array}$ & $\begin{array}{l}\text { These dimension scores countries according to policies governments pursued to deregulate } \\
\text { and encourage the development of bond, equity and derivative markets. }\end{array}$ \\
\hline $\begin{array}{l}\text { Barriers to entry in the } \\
\text { banking sector }\end{array}$ & $\begin{array}{l}\text { OECD (Denk and Gomez, } \\
\text { 2017) }\end{array}$ & $\begin{array}{l}\text { This dimension captures barriers to entry for foreign and domestic banks into the domestic } \\
\text { banking system, restrictions on the geographic area where banks can operate and restrictions } \\
\text { on the scope of bank activities. }\end{array}$ \\
\hline $\begin{array}{l}\text { Privatisation of the banking } \\
\text { sector }\end{array}$ & $\begin{array}{l}\text { OECD (Denk and Gomez, } \\
\text { 2017) }\end{array}$ & $\begin{array}{l}\text { This index assesses the extent to which the government directly participates in banking } \\
\text { activities through the ownership of bank assets. }\end{array}$ \\
\hline Interest rate control & $\begin{array}{l}\text { OECD (Denk and Gomez, } \\
\text { 2017) }\end{array}$ & $\begin{array}{l}\text { This dimension characterises the extent to which regulations restrict banks in setting lending } \\
\text { and deposit rates. }\end{array}$ \\
\hline $\begin{array}{l}\text { Strength of legal rights } \\
\text { Need resolving solvency }\end{array}$ & $\begin{array}{l}\text { Doing Business database. } \\
\text { World Bank }\end{array}$ & $\begin{array}{l}\text { This index measures the degree to which collateral and bankruptcy laws protect the rights of } \\
\text { borrowers and lenders and thus facilitate lending. The index is calculated by sorting the } \\
\text { distance of each economy to frontier scores and goes from } 0 \text { to } 12 \text {. }\end{array}$ \\
\hline Contract enforcement & $\begin{array}{l}\text { Doing Business database. } \\
\text { World Bank }\end{array}$ & $\begin{array}{l}\text { The index measures the time and cost for resolving a commercial dispute through a local first- } \\
\text { instance court and the quality of judicial processes. The index is calculated by sorting the } \\
\text { distance of each economy to frontier scores and goes from } 0 \text { to } 120 \text {. }\end{array}$ \\
\hline $\begin{array}{l}\text { Transparency of credit } \\
\text { information }\end{array}$ & $\begin{array}{l}\text { Doing Business database. } \\
\text { World Bank }\end{array}$ & $\begin{array}{l}\text { Depth of credit information index measures rules affecting the scope, accessibility, and quality } \\
\text { of credit information available through public or private credit registries. The index is } \\
\text { calculated by sorting the distance of each economy to frontier scores and goes from } 0 \text { to } 100 \text {. }\end{array}$ \\
\hline
\end{tabular}




\section{Unlocking the growth potential of intangible assets through financial development}

\subsection{The effect of finance on intangible-intensive sectors}

36. Table 2 reports the results of the baseline specification. The interaction term estimates suggest that labour productivity grows faster in intangible intensive sectors in more financially developed countries (columns 1-3). The table reports estimates using time invariant measures of financial development (market capitalisation to GDP and domestic credit to GDP) and time-varying measures produced by the IMF. ${ }^{9}$ Splitting intangible intensity into knowledge capital and organisation capital (column 4) indicates that the effect of financial development on productivity growth is stronger for sectors relatively more intensive in knowledge capital compared to sectors relatively more intensive in organisational capital. Knowledge-based intangible capital (e.g. patents) relies on substantive longer-term and often riskier investments than organisation-based capital. It is therefore unsurprising that financial development has a stronger impact on productivity growth of sectors intensive in knowledge-based assets. Results are also robust to the inclusion of other country-level variables that might generate higher productivity growth for intangible-intensive sectors (column 5 and Table A.6). ${ }^{10}$

37. Figure 8 provides an alternative depiction of forces at work showing productivity growth by intangible-intensity quintiles and level of financial development, after removing the effects of catching-up, capital stock and sector and country-year fixed effects estimated from Equation 1. A positive relationship between labour productivity growth and intangible intensity appears for financially well-developed countries, while such pattern does not emerge for financially less-developed countries, in line with previous results. Overall, empirical findings confirm that financial development, supported by adequate policies, could contribute to release untapped growth potential in intangible intensive sectors.

\footnotetext{
${ }^{9}$ The sign and the magnitude of the interaction coefficient are consistent and robust across different proxies for intangible intensity and components of the IMF financial development index (Table A.5). In particular, the results are robust to using our time-varying measure of the IntangIntens, lessening the concern that results are driven by the substitution between tangible and intangible assets that we observed over time and documented by Haskel and Westlake (2018).

${ }^{10}$ One potential concern is that productivity growth captures an increase in mark-ups and not an efficiency gain (Crouzet and Eberly, 2018). However, our sector-level productivity calculations use industry specific deflators, therefore alleviating any confounding effects resulting from market power.
} 
Figure 8. The effects of financial development on productivity growth conditional on intangible intensity

\section{Labor Productivity Growth}

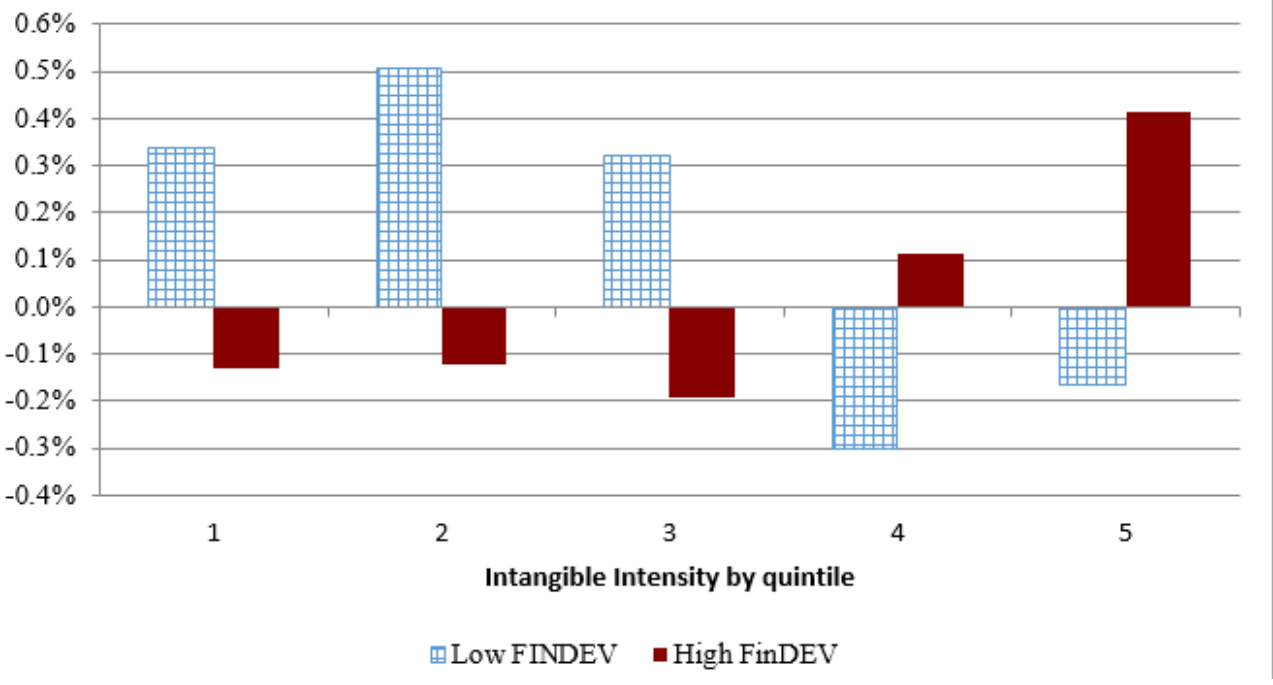

Note: The figure shows the labour productivity growth across countries (excluding U.S.) by intangible intensity quintiles after removing the effects of catching-up, capital stock and sector and country-year fixed effects. Labour productivity is calculated as value added per employee. Intangible asset intensity is defined as the median sector-level value of the ratio between intangible assets and total assets. It is calculated for all U.S. listed firms in Compustat from 1990-2006, excluding financial, utilities and public service. Source: OECD, STAN database, Compustat. 
Table 2. The links between financial development, intangible intensity and productivity

\begin{tabular}{|c|c|c|c|c|c|c|}
\hline Dep variable: Labour Productivity Growth & (1) & (2) & (3) & (4) & (5) & (6) \\
\hline FinDEV variable: & $\begin{array}{l}\text { Market cap } \\
\text { (initial) }\end{array}$ & $\begin{array}{c}\text { Domestic } \\
\text { credit } \\
\text { (initial) }\end{array}$ & $\begin{array}{l}\text { IMF Global } \\
\text { Fin Index }\end{array}$ & $\begin{array}{l}\text { IMF Global } \\
\text { Fin Index }\end{array}$ & $\begin{array}{l}\text { IMF Global } \\
\text { Fin Index }\end{array}$ & $\begin{array}{l}\text { IMF Global } \\
\text { Fin Index }\end{array}$ \\
\hline Initial Labour Productivity & $-0.025^{\star * *}$ & $-0.025^{\star * *}$ & $-0.021^{\star * *}$ & $-0.022^{* * *}$ & $-0.024^{* * *}$ & $-0.021^{* \star *}$ \\
\hline Change Capital Stock & $(0.099)$ & $(0.098)$ & $(0.125)$ & $(0.125)$ & $(0.114)$ & $(0.125)$ \\
\hline \multirow[t]{2}{*}{ FinDEV * IntangIntens } & $0.465^{\star * *}$ & $0.383^{* * *}$ & $0.076^{* *}$ & & $0.096^{*}$ & \\
\hline & $(0.007)$ & $(0.002)$ & $(0.012)$ & & $(0.077)$ & \\
\hline FinDEV * IntangIntens (knowledge) & & & & $0.088^{* * *}$ & & \\
\hline \multirow[t]{2}{*}{ GDP growth * IntangIntens } & & & & & -0.004 & \\
\hline & & & & & $(0.436)$ & \\
\hline \multirow[t]{2}{*}{ Inflation * IntangIntens } & & & & & 0.000 & \\
\hline & & & & & $(0.775)$ & \\
\hline \multirow[t]{2}{*}{ Labour regulation * IntangIntens } & & & & & -0.008 & \\
\hline & & & & & $(0.141)$ & \\
\hline \multirow[t]{2}{*}{ FinDEV * IntangIntens } & & & & & & 0.048 \\
\hline & & & & & & $(0.253)$ \\
\hline FinDEV * IntangIntens * dFinDEP § & & & & & & $0.088^{* *}$ \\
\hline Country-Year FE & YES & YES & YES & YES & YES & YES \\
\hline Sector FE & YES & YES & YES & YES & YES & YES \\
\hline
\end{tabular}

Note: The dependent variable is the labour productivity growth. IntangIntens is intangible asset intensity. Columns (1) to (3) use alternative definitions for financial development. Column (4) expands the definition of intangible assets intensity based on their source, knowledge- or organisation-based. Column (5) includes additional country level variables, such as GDP growth, inflation and labour regulation, interacted with IntangIntens. Column (6) includes the triple interaction with dFinDEP, where dFinDEP is a categorical variable equal to 1 if above zero and 0 otherwise. ${ }^{\S}$ indicates that the presented coefficient is equal to the sum of $\beta_{1}+\beta_{3}$ as described in the text (see equations 2 and 3). All regressions include sector and country-year fixed effects. Standard errors are clustered at the industry level and pvalues are presented in parenthesis. ${ }^{*}, * *, * * *$ denote statistical significance at the $10 \%, 5 \%$ and $1 \%$ levels.

Source: Compustat, STAN database 


\section{Box 3. Channels linking productivity and intangible assets intensity}

One way to explore the channels through which financial development can affect productivity growth of intangible-intensive sectors is to focus on their effect on the collateral constraint (see Section 2). Indeed, financial development is likely to relax the constraint related to the difficulty of pledging intangibles as a collateral. To examine the collateral channel, the following equations are estimated, focusing on one particular intangible asset, $R \& D$, under the assumption that the amount of collateral available in a sector can be proxied by the outstanding stock of tangible capital:

$$
\begin{gathered}
\Delta \log R D_{c, j, t+1}=\beta_{0}+\beta_{1}\left(\log K_{c, j, t}\right)+\beta_{2}\left(\log K_{c, j, t} \times \operatorname{Int} K_{j}\right)+\beta_{3} \Delta \log K_{c, j, t}+\eta_{c, t}+\mu_{j}+s_{c, j, t+1} \\
\Delta \log R D_{c, j, t+1}=\beta_{0}+\beta_{1}\left(\log K_{c, j, t}\right)+\beta_{2}\left(\Delta \log K_{c, j, t} \times \operatorname{Int} K_{j}\right)+\beta_{3}\left(\log K_{c, j, t} \times \operatorname{Int} K_{j} \times F i n D E V_{c, t}\right)+ \\
\beta_{4}\left(\Delta \log K_{c, j, t} \times F \operatorname{FinDEV} V_{c, t}\right)+\beta_{5}\left(\operatorname{Int} K_{j} \times F i n D E V_{c, t}\right)+\beta_{6} \Delta \log K_{c, j, t}+\eta_{c, t}+\mu_{j}+s_{c, j, t+1}
\end{gathered}
$$

Where RD stands for R\&D expenditure in country $\mathrm{c}$ and sector $\mathrm{j}$ at time $\mathrm{t}, \mathrm{K}$ is the stock of tangible capital, IntK is our measure of sectoral intangible-intensity, FinDEV is a measure of financial development and $\eta$ and $\mu$ are fixed effects.

Table 3. A collateral constraint reins in $R \& D$ investment especially in intangible sectors and financially less-developed countries

\begin{tabular}{lccc}
\hline & $(1)$ & $(2)$ & $(3)$ \\
\hline Dependent variable & R\&D Growth & R\&D Growth & R\&D Growth \\
\hline & & & \\
R\&D Growth (lag) & $-0.107^{* * *}$ & $-0.090^{* *}$ & \\
CapitalStock & $(0.031)$ & $(0.041)$ & \\
& $0.009^{*}$ & $-0.018^{*}$ & -0.023 \\
Change CapitalStock & $(0.005)$ & $(0.010)$ & $(0.016)$ \\
& $0.626^{* * *}$ & $0.577^{* * *}$ & $1.189^{*}$ \\
IntntangIntens * CapitalStock & $(0.162)$ & $(0.173)$ & $(0.605)$ \\
& $0.017^{* *}$ & 0.050 & 0.042 \\
IntangIntens * CapitalStock * dFinDEV $\S$ & $(0.008)$ & $(0.032)$ & $(0.043)$ \\
& & $0.058^{* * *}$ & $0.060^{* * *}$ \\
IntangIntens *dFinDEV & & $(0.016)$ & $(0.013)$ \\
& & -0.412 & -0.000 \\
CapitalStock * dFinDEV & & $(0.377)$ & $(0.000)$ \\
& & $-0.027^{*}$ & -0.025 \\
Observations & & $(0.013)$ & $(0.016)$ \\
R-squared & 3,345 & 3,617 \\
Country-Year FE & 4,831 & 0.167 & 0.157 \\
Sector FE & 0.168 & YES & YES \\
\hline
\end{tabular}

Note: The dependent variable is the growth of R\&D expense, defined at country-sector level. The intangible asset intensity is defined as the median sector-level value of the ratio between intangible assets and total assets. $\mathrm{dFinDEV}$ is a categorical variable equal to one if above the IMF Global Fin Index and zero otherwise. Capital stock refers to the total tangible assets (such as plant and equipment). Standard errors are clustered at the industry level and pvalues are presented in parenthesis. *,**, *** denote statistical significance at the $10 \%$, $5 \%$ and $1 \%$ levels. Source: See Glossary. 
The idea is to explore whether increases in the physical capital stock (the proxy for collateral) has a noticeable impact on R\&D spending (equation 1 above) and then whether financial development helps to relax further the collateral constraint (Equation 2). To facilitate the interpretation of results, a categorical variable for financial development dFinDEV is created based on country-year medians.

The positive coefficient of the interacted term (column 1) suggests that a collateral constraint undermines investment in intangible assets such as R\&D and that this effect is stronger for intangible-intensive sectors: a relatively larger stock of tangible capital can help those sectors to relax the constraint and invest more in R\&D. The positive sign of the triple interaction term (column 2) provides suggestive evidence that financial development further helps to relax the collateral constraint. Results are robust to an alternative contemporaneous specification of R\&D (see Hsu et al., 2017) (column 3).

\subsection{The additional effect of dependence to external finance}

38. As expected, the effects of financial development on productivity growth are stronger in sectors that are at the same time intensive in intangible assets and dependent on external finance, reflecting the presence of several sources of financial frictions (see Table 2, column 6). The combined effect of intangible intensity and external financial dependence (equation 3) is illustrated in Figure 9. Overall, industries that are more intensive in intangible assets benefit relatively the most from financial development when they are also dependent on external finance, suggesting that intangible assets intensity and external dependence complement each other in amplifying the effect of financial frictions on productivity growth. It is important to note that sectors with an intensity in intangible assets above $56 \%$ account broadly for one-third of the sample (see Table A.1). By contrast, no significant effect of financial development is found for sectors that are dependent on external finance but characterized by lower intangible intensity or sectors that are less dependent on external finance but intangible-intensive (Table A.1).

39. These findings suggest that financial development, supported by appropriate policies, could help countries tapping on the stronger productivity growth potential of intangible-intensive sectors. The economic impact is substantial and permanent as our main variable of interest is productivity growth. For example, a sector that has about $66 \%$ of assets in intangible assets (such as Computer Equipment) experiences annual labour productivity growth that is one percentage point larger in Japan (i.e. a country at the $75 \%$ percentile of financial development) than Portugal (at the $25 \%$ percentile of financial development). Moreover, policies are likely to be most effective at boosting productivity if they lead to lower financial frictions primarily for sectors highly intensive in intangible assets and dependent on external finance. This warrants a closer focus on the kind of policies that would help achieving these productivity gains. 
Figure 9. The effects of financial development on productivity growth conditional on intangible intensity and external financial dependence
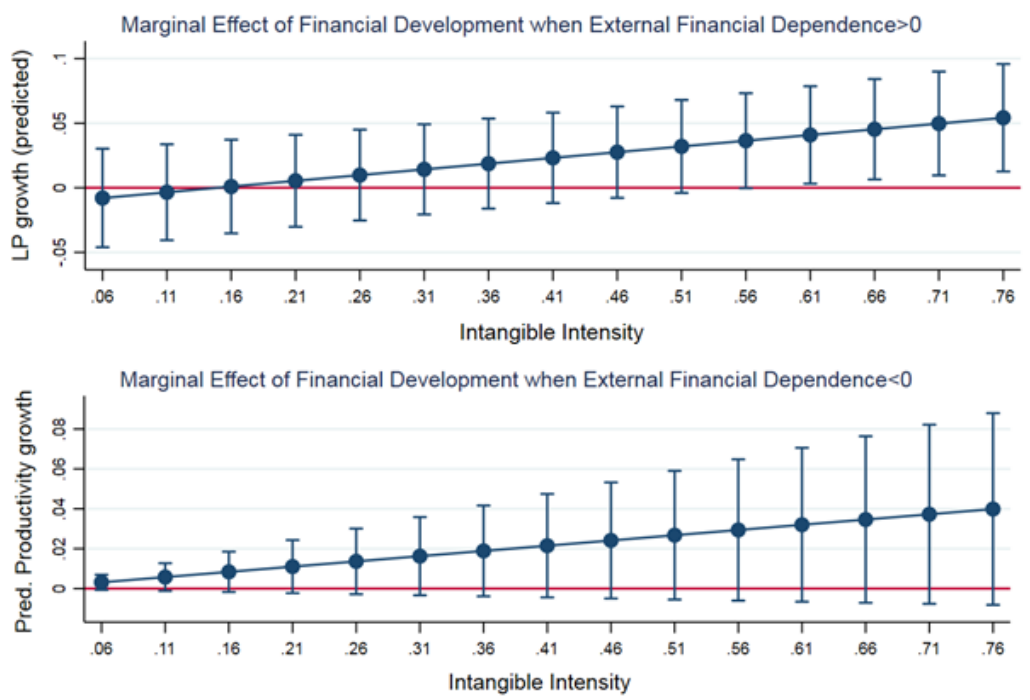

Note: The figure shows the marginal effects (equation 3) separately for positive financial dependence (on top) and negative financial dependence (on bottom). Marginal effects are estimated using the regression presented in Table 2, column 6. Vertical lines report confidence intervals and show non-significant effects when the value zero is within the interval.

Source: OECD's calculations.

\subsection{The role of policies and framework conditions}

40. Policies that support financial development and help overcoming the financial frictions highlighted in this paper include those encouraging the diversification of finance and establishing framework conditions that improve the ability of the financial system to channel capital to the most innovative sectors. We therefore explore the effects of developing non-bank finance, reforming financial and banking sector regulations and establishing a sound legal business environment. To establish a causal relationship between policies and productivity growth are identification relies on the exogenous sector-level (and time-invariant) measure of intangible intensity (similar to Rajan and Zingales, 1998).

\subsubsection{Equity financing}

41. To examine the role of the structure of finance in fueling productivity growth of intangible sectors, the generic measure of dependence on external finance (equation 2) is replaced by a measure of equity external dependence (see Box 1). The coefficient of the triple interaction term is positive and significant, confirming a stronger effect of financial development on productivity growth in externally dependent intangible-intensive sectors that rely more on equity finance (Table 4, column 1 and Figure A.2).

42. A direct test of the importance of equity financing for productivity is also undertaken, looking at the impact of venture capital and private equity (Table 4, column 2$3)$. The estimation is similar to the baseline specification and relies on the same identification strategy. Results suggest that access to venture capital or private equity 
incrementally boosts the productivity of intangible-intensive sectors. ${ }^{11}$ Overall, those results suggest that policies aimed at strengthening equity markets and more specifically venture capital could promote productivity growth of the most innovative sectors. A wide range of policies can potentially affect the size and the role of private equity markets for innovation, either by directly reducing the cost of investing in private equity or by shaping the expectations on future returns from those investments such as tax policies (e.g. tax deduction associated to investment in corporation, bias in the tax system in favour of debt, tax relief on capital gains), innovation policies (regulation governing exit options from venture capital investment and the type of institutional investors which is allowed to invest, intellectual property rights regulation, $R \& D$ tax reliefs) and the business legal environment (labour and product market regulation, disclosure rules). Investigating the respective impact of those policy instruments on the development of private equity markets is left for future research.

Table 4. The type of finance matters for productivity growth in intangible intensive sectors

\begin{tabular}{|c|c|c|c|}
\hline Dependent variable: Labour Productivity Growth & (1) & (2) & (3) \\
\hline \multirow[t]{2}{*}{ Initial Labour Productivity } & $-0.021^{* * *}$ & -0.016 & $-0.022^{\star * *}$ \\
\hline & $(0.000)$ & $(0.141)$ & $(0.000)$ \\
\hline \multirow[t]{2}{*}{ Change Capital Stock } & 0.078 & $0.214^{\star *}$ & $0.102^{*}$ \\
\hline & $(0.128)$ & $(0.030)$ & $(0.056)$ \\
\hline \multirow[t]{2}{*}{ FinDEV * IntangIntens } & -0.037 & & \\
\hline & $(0.701)$ & & \\
\hline \multirow[t]{2}{*}{ FinDEV * IntangIntens * dEquityFinDEP § } & $0.086^{* * *}$ & & \\
\hline & $(0.004)$ & & \\
\hline \multirow[t]{2}{*}{ FinDEV *dEquityFinDEP } & -0.050 & & \\
\hline & $(0.246)$ & & \\
\hline \multirow[t]{2}{*}{ IntangIntens ${ }^{*} \mathrm{VC}$} & & $0.471^{*}$ & \\
\hline & & $(0.063)$ & \\
\hline \multirow[t]{2}{*}{ IntangIntens*PrivateEquity } & & & $0.031^{* *}$ \\
\hline & & & $(0.015)$ \\
\hline Observations & 7,221 & 2,947 & 6,113 \\
\hline R-squared & 0.144 & 0.106 & 0.118 \\
\hline Country-Year FE & YES & YES & YES \\
\hline Sector FE & YES & YES & YES \\
\hline
\end{tabular}

Note: The dependent variable is the labour productivity growth. dEquityFinDEP is a categorical variable equal to one if equity external dependence is positive and zero otherwise. Intangible asset intensity is defined as the median sector-level value of the ratio between intangible assets and total assets. FinDEV is the IMF Global Financial Index. Venture capital and private equity are country-level variables. All regressions include sector and country-year fixed effects. ${ }^{\S}$ indicates that the presented coefficient is equal to the sum of $\beta_{1}+\beta_{3}$ as described in the text (see equations 2 and 3). Robust standard errors are clustered at the industry level and pvalues are presented in parenthesis. $*, * *, * *$ denote statistical significance at the $10 \%, 5 \%$ and $1 \%$ levels.

Source: Compustat, IMF, Eurostat.

\subsubsection{Financial and banking sector regulation}

43. Barriers to competition in the financial sector may impact the ability of the financial sector to channel finance to the most productive firms and to provide finance to new entrants

${ }^{11}$ Due to a break in the series, data are only available from 2006 which reduces the size of the sample (Table 4, column 3). 
(see section 2). Two types of variables are used to proxy for the degree of competition in the financial sector. The first variable is an outcome of pro-competitive policies, namely the degree of banking concentration (measured as the share of the top three banks in total assets in each country). The second variable relies on a regulatory index first established by the IMF (Abiad et al, 2010), but recently updated by Denk and Gomez (2017).

44. The regression results indicate that banking concentration has an adverse effect on productivity growth in intangible-intensive sectors especially for financially welldeveloped countries. This suggests that pro-competitive reforms amplify the positive effect of financial development in intangible-intensive sectors (Table 5, column 1), possibly by increasing the efficiency of services, lowering the cost of finance, and improving the access of funding to new entrants.

45. Results for the financial regulation index indicate that policies promoting on average both liberalised and stable financial markets boost productivity growth in intangible intensive sectors (Table 5, column 2). Looking at the subcomponents of the index, features that appear important are lowering barriers to entry in the banking sector, lifting interest rate controls, liberalising securities market and reducing the share of stateowned banks. Results also suggest that the effects of these reforms may vary according to the level of financial development. In financially less-developed countries, important policy features supporting productivity growth of intangible-intensive sectors include reducing the share of state-owned banks, lifting barriers to entry in banking and removing interest rate controls. In financially well-developed countries, liberalisation of securities market seems more critical for strengthening the impact of finance. 
Table 5. The effects of competition and financial regulations

\begin{tabular}{|c|c|c|c|c|c|c|}
\hline & (1) & (2) & (3) & (4) & (5) & (6) \\
\hline $\begin{array}{l}\text { Dep variable: Labour Productivity } \\
\text { Growth }\end{array}$ & $\begin{array}{c}\text { Bank } \\
\text { concentration }\end{array}$ & $\begin{array}{c}\text { Financial reform } \\
\text { Index (Denk } \\
\text { Gomez) }\end{array}$ & $\begin{array}{l}\text { Interest Rate } \\
\text { Liberalization }\end{array}$ & $\begin{array}{l}\text { Bank } \\
\text { sector } \\
\text { entry }\end{array}$ & Privatization & $\begin{array}{c}\text { Securities } \\
\text { market policies }\end{array}$ \\
\hline \multirow[t]{2}{*}{ Initial Labour Productivity } & $-0.018^{\star \star *}$ & $-0.020^{\star * *}$ & $-0.022^{\star * *}$ & $-0.022^{* * *}$ & $-0.022^{\star * *}$ & $-0.022^{* * *}$ \\
\hline & $(0.006)$ & $(0.005)$ & $(0.004)$ & $(0.004)$ & $(0.004)$ & $(0.004)$ \\
\hline \multirow[t]{2}{*}{ Change Capital Stock } & 0.057 & 0.062 & 0.063 & 0.062 & 0.060 & 0.064 \\
\hline & $(0.058)$ & $(0.051)$ & $(0.050)$ & $(0.050)$ & $(0.051)$ & $(0.051)$ \\
\hline \multirow[t]{2}{*}{ IntangIntens * Policy } & -0.000 & $0.132^{* *}$ & $0.681^{* * *}$ & $0.215^{\star *}$ & $0.049^{* * *}$ & 0.016 \\
\hline & $(0.001)$ & $(0.055)$ & $(0.029)$ & $(0.084)$ & $(0.017)$ & $(0.179)$ \\
\hline \multirow[t]{2}{*}{ IntangIntens * Policy * dFinDEV } & $-0.001^{*}$ & -0.024 & -0.000 & 0.131 & -0.006 & $1.389^{\star * *}$ \\
\hline & $(0.000)$ & $(0.080)$ & $(0.043)$ & $(0.114)$ & $(0.033)$ & $(0.323)$ \\
\hline \multirow[t]{2}{*}{ IntangIntens * dFinDEV } & 0.038 & 0.147 & $0.688^{* * *}$ & 0.09 & $0.044^{*}$ & $1.365^{\star * *}$ \\
\hline & $(0.070)$ & $(0.088)$ & $(0.046)$ & $(0.169)$ & $(0.023)$ & $(0.379)$ \\
\hline Observations & 5,477 & 6,806 & 7,040 & 7,040 & 7,040 & 7,040 \\
\hline R-squared & 0.126 & 0.140 & 0.140 & 0.140 & 0.140 & 0.140 \\
\hline Country-Year FE & YES & YES & YES & YES & YES & YES \\
\hline Sector FE & YES & YES & YES & YES & YES & YES \\
\hline
\end{tabular}

Note: Bank concentration measures the assets of three largest commercial banks as a share of total commercial banking assets. Financial reform index characterizes the regulation of the financial sector along several dimensions (the index goes from 0 to 1 ). Interest rate liberalization characterises the extent to which regulations restrict banks in setting lending and deposit rates. Bank sector entry captures barriers to entry for foreign and domestic banks into the domestic banking system, restrictions on the geographic area where banks can operate and restrictions on the scope of bank activities. Privatization assesses the extent to which the government directly participates in banking activities through the ownership of bank assets. Securities market policies scores countries according to policies governments pursued to deregulate and encourage the development of bond, equity and derivative markets. All regressions include sector and country-year fixed effects. ${ }^{\S}$ indicates that the presented coefficient is equal to the sum of $\beta_{1}+\beta_{3}$ as described in the text (see equation 4). Robust standard errors are clustered at the industry level and pvalues are presented in parenthesis. $*, * *, * * *$ denote statistical significance at the $10 \%, 5 \%$ and $1 \%$ levels.

Source: World Bank Global Financial Development database and IMF.

\subsubsection{The legal business environment}

46. The legal business environment is also likely to influence the financial development-productivity nexus. Establishing a legal framework for entrepreneurs that secures the return from their investment and that limits personal costs in case of failures shapes the incentives to undertake investments in innovative activities. The results reported in Table 6 (Columns 1-2) provide some evidence that the ease of insolvency procedures and of enforcing contracts could contribute to increasing the positive effect of financial development on productivity growth in intangible-intensive sectors. These features take on heightened importance for financially less-developed countries.

47. Finally, the effect of regulations allowing more transparency in credit information is explored using an index of rules and practices affecting the coverage, scope and accessibility of credit information available through either a credit bureau or a credit registry. The coefficient of the triple interaction is positive and significant, confirming the importance of reducing information asymmetry between borrowers and creditors (Table 6 , column 3). As suggested by the estimates, this could be particularly important for financially well-developed countries. Indeed, the availability of credit and its access to small firms is broader at higher levels of financial development, implying that credit 
transparency may play a heightened role. Moreover, investors who lack information on small and young firms may rely on such credit record to assess the financial capacity of firms. More research is needed in the future to better understand these channels.

Table 6. The effect of the legal business environment

\begin{tabular}{lccc}
\hline & $(1)$ & $(2)$ & $(3)$ \\
\hline Dependent variable: Labour Productivity Growth & Resolve Insolvency & Enforcing Contracts & Depth Credit Info \\
& & & \\
Initial Labour Productivity & $-0.015^{*}$ & -0.011 & $-0.018^{*}$ \\
& $(0.008)$ & $(0.012)$ & $(0.010)$ \\
Change Capital Stock & 0.095 & 0.098 & 0.051 \\
& $(0.066)$ & $(0.073)$ & $(0.086)$ \\
IntangIntens * Policy & $0.001^{*}$ & $0.003^{*}$ & -0.000 \\
& $(0.001)$ & $(0.002)$ & $(0.000)$ \\
IntangIntens * Policy * dFinDEV § & -0.001 & -0.001 & $0.001^{* *}$ \\
& $(0.001)$ & $(0.001)$ & $(0.000)$ \\
IntangIntens * FinDEV & $0.128^{*}$ & $0.269^{* *}$ & -0.079 \\
& $(0.071)$ & $(0.120)$ & $(0.063)$ \\
Observations & & & \\
R-squared & 4,288 & 4,039 & 3,391 \\
Country-Year FE & 0.133 & 0.140 & 0.142 \\
Sector FE & YES & YES & YES \\
\hline
\end{tabular}

Note: Resolving Insolvency captures to cost and outcome of insolvency proceedings involving domestic entities as well as the strength of the legal framework applicable to judicial liquidation and reorganisation proceedings. Enforcing contracts captures the time and cost for resolving a commercial dispute through a local first-instance court and the quality of judicial processes index. It evaluates whether countries have adopted a series of good practices that promote quality and efficiency in the court system. Depth of credit information index measures rules and practices affecting the coverage, scope and accessibility of credit information available through either a credit bureau or a credit registry. $\S$ indicates that the presented coefficient is equal to the sum of $\beta_{1}+\beta_{3}$ as described in the text (see equation 4). Robust standard errors are clustered at the industry level and pvalues are presented in parenthesis. $*, * *, * * *$ denote statistical significance at the $10 \%, 5 \%$ and $1 \%$ levels.

Source: World Bank Doing Business database, Compustat, STAN database.

48. The economic impact of policy reforms on productivity growth of intangible sectors is potentially considerable. To get a sense of the magnitude of the effects, Figure 10 reports these findings graphically. The figure shows the differential effect of reforms on industries with high and low intangible assets intensity. High intangible-intensive industries are defined at the $75^{\text {th }}$ percentile and refer to sectors with an intangible intensity equal or above $60 \%$. Low intangible intensive industries are defined at the $25^{\text {th }}$ percentile and refer to sectors with an intangible intensity below $30 \%$. The size of the additional gains for high intangible sectors depends on the magnitude of the policy shocks. For the components of the financial regulatory index, which have a more discrete and skewed distribution, a dramatic shock (i.e. a move from the $5^{\text {th }}$ to the $95^{\text {th }}$ percentile) allow an interpretation of the results that is better aligned to the data. For the business legal environment variables, which have a more continuous distribution, a moderate shock (i.e. a move from the $25^{\text {th }}$ to the $75^{\text {th }}$ percentile) allow for more incremental interpretation of the results.

49. Overall results suggest that bringing regulation settings close to the most liberalised countries in terms of interest rate control, barriers to bank entry, privatisation and securities market regulation, could be associated with additional productivity growth gains for intangible-intensive sectors between 0.5 to 2.5 percentage points. Simulations suggest that 
improvements of the overall regulation of the financial system, for instance from the level observed in Portugal to the level observed in Finland, could add up to 0.6 additional percentage point of productivity growth in intangible intensive sectors. Effects of similar size could be obtained by improving credit transparency, for instance from the level observed in France to the level observed in Japan. Larger productivity growth gains in the intangible sectors are associated with reforms that would establish contract enforcement laws close to the best practices, up to one percentage point if for instance Greece would move to the level observed in Island. The differential of productivity gains would be even larger, of up to 1.5 additional percentage points, when establishing business friendly insolvency regimes (from the level observed in Portugal to the one observed in Austria).

Figure 10. Economic significance of policy changes on relative productivity growth of intangible-intensive sectors

Differential impact between industries with high and low knowledge intensity

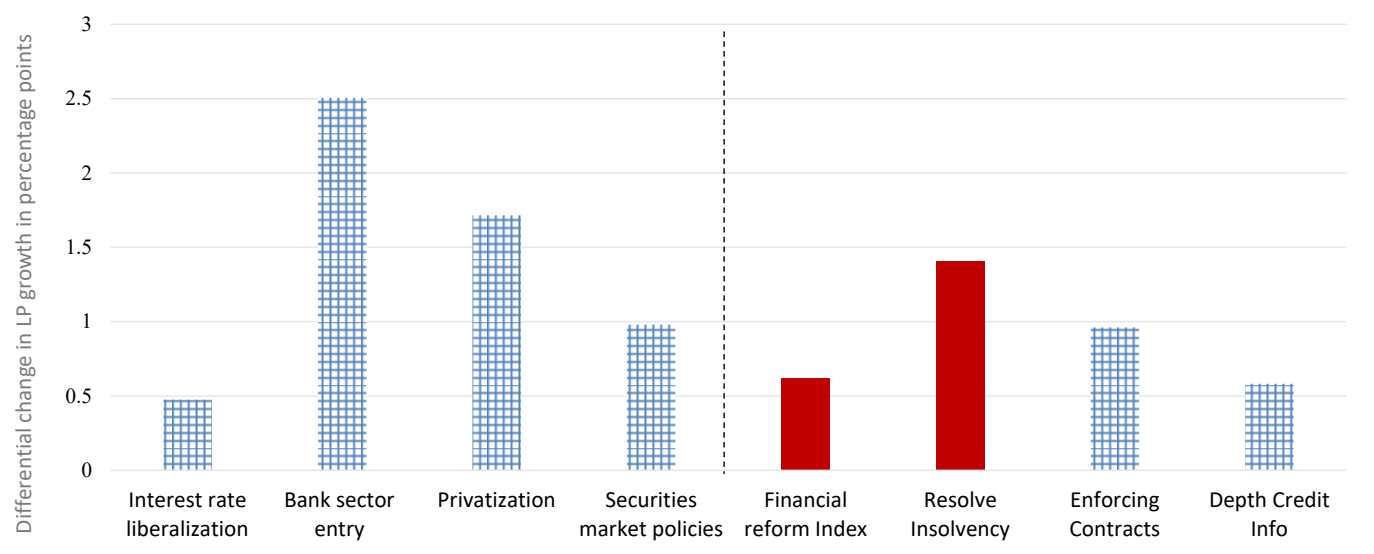

Note: The figure shows the difference in labour productivity growth (in percentage points) between high and low intangible intensive sectors following various policy changes. High (low) intangible-intensive sectors are defined at the $75^{\text {th }}\left(25^{\text {th }}\right)$ percentile of the distribution. Estimated effects are computed based on the coefficients reported in tables 4 and 5 and a change of the policy variable from the $25^{\text {th }}$ to the $75^{\text {th }}$ percentile of their distribution. Policy changes for the financial reform index components (shown at the left of the figure) are larger, from the $5^{\text {th }}$ to the $95^{\text {th }}$ percentile due to their skewed distribution. The figure reports only the significant effects, with dotted bars in financially less-developed countries and solid bars for financially well-developed countries.

Source: OECD's calculations

\section{Conclusion}

50. This paper provides a new analytical framework to investigate the link between finance and productivity growth. While past research has mainly focused on the frictions induced by dependence to external finance, we add a new source of financial frictions by taking into account intangible assets. This approach is motivated by the rise of intangible assets in OECD countries over the last two decades and the observation that some countries have not exhausted the growth potential associated with these assets. Taken at face value, the results suggest that financial frictions in intangible sectors have been a barrier to productivity growth in financially less-developed countries and that several policies could magnify this positive effect, such as liberalizing banking and financial markets, 
encouraging the development of equity markets and establishing a business friendly legal environment.

51. While the sectoral focus and the identification strategy point to a strong link between financial development and productivity growth, it does not allow exploring in depth the channels through which financial policies can affect productivity. Use of firm level data could shed additional light on these channels by taking advantage of information on firms' financial characteristics (such as leverage, cash holdings, and investment) and firm's performance at different points of the size and productivity distributions. This could also allow for a more direct assessment of whether the benefits of finance and policies operate through an improvement of within firms' performance or through allocative efficiency. 


\section{References}

Abiad, A., E. Detragiache and T. Tressel (2010), "A New Database of Financial Reforms", IMF Staff Papers, vol.57(2), pp.281-302.

Acharya, V. and Z. Xu (2017), "Financial dependence and innovation: The case of public versus private firms", Journal of Financial Economics, vol.124(2), pp.223-243.

Adalet McGowan, M. and D. Andrews (2017), "Skills mismatch, productivity and policies: Evidence from the second wave of PIAAC", OECD Economics Department Working Papers, No.1403, OECD Publishing, Paris.

Aghion, P., G.-M. Angeletos, A. Banerjee, and K. Manova (2010), "Volatility and growth: Credit constraints and the composition of investment", Journal of Monetary Economics, Elsevier, vol. 57(3), pp.246-265.

Aghion, P., P. Askenazy, N. Berman, G. Cette, and L. Eymard (2012a), Credit constraints and the cyclicality of R\&D investment: Evidence from France, Journal of the European Economic Association, vol.10(5), pp.1001-1024.

Aghion, P., Farhi, E., \& Kharroubi, E. (2012), "Monetary policy, liquidity, and growth", NBER Working Paper No.18072, National Bureau of Economic Research, Inc.

Akerlof G.A., (1970), "The Market for "Lemons": Quality Uncertainty and the Market Mechanism George A.”, Quarterly Journal of Economics, vol.84 (3), pp.488-500.

Alfaro I., N. Bloom, and X. Lin (2018), “The Finance-Uncertainty Multiplier", Stanford University Working Paper, No. 18-020.

Almeida, H. and M. Campello (2007), "Financial Constraints, Asset Tangibility, and Corporate Investment", Review of Financial Studies 20 (5), pp.1429-1460.

Andrews, D., Nicoletti G., and C. Timiliotis, (2018), "Digital technology diffusion: A matter of capabilities, incentives or both?", OECD Economics Department Working Papers, No. 1476, OECD Publishing, Paris.

Andrews, D. and C. Criscuolo (2013), "Knowledge-Based Capital, Innovation and Resource Allocation", OECD Economics Department Working Papers, No. 1046, OECD Publishing, Paris.

Andrews, D., C. Criscuolo and C. Menon (2014), "Do Resources Flow to Patenting Firms?: Cross-Country Evidence from Firm Level Data", OECD Economics Department Working Papers, No. 1127, OECD Publishing, Paris.

Andrews, D. and A. De Serres (2012), Intangible assets, Resource allocation and Growth: A Framework for Analysis, OECD Economics Department Working Papers, N.989, OECD Publishing, Paris.

Andrews, D., C. Criscuolo, and P. N. Gal (2016), "The Best versus the Rest: The Global Productivity Slowdown, Divergence across Firms and the Role of Public Policy", OECD Productivity Working Papers No.5, OECD Publishing, Paris.

Bai, J. J., D. Carvalho, and G. M. Phillips (2017), "The Impact of Bank Credit on Labor Reallocation and Aggregate Industry Productivity”, NBER Working Papers No.24081, National Bureau of Economic Research, Inc. 
Bartelsman, E., J.C. Haltiwanger, and S. Scarpetta (2004), "Microeconomic Evidence of Creative Destruction in Industrial and Developing Countries", IZA Discussion Papers No.1374, Institute for the Study of Labor (IZA).

Barth, M. E. , R. Kasznik and M. F. McNichols (2001), “Analyst coverage and intangible assets”, Journal of Accounting Research, Vol. 39 (1), pp. 1-34.

Bassanini, A., L. Nunziata and D. Venn (2009), "Job Protection Legislation and Productivity Growth in OECD Countries," Economic Policy, vol. 24, no. 58, pp. 349-402.

Benfratello, Luigi, Fabio Schiantarelli, and Alessandro Sembenelli (2008), "Banks and innovation: Microeconometric evidence on Italian firms," Journal of Financial Economics 90 (2), pp.197-217.

Bloom, N., M. Draca and J.Van Reenen (2012), "Management Practices Across Firms and Countries", NBER Working Paper, No.17850, National Bureau of Economic Research, Inc.

Braumoeller, B. F. (2004), "Hypothesis testing and multiplicative interaction terms", International Organization, vol.58 (4), pp.807-820.

Brown, J. R., S. M. Fazzari, and B. C. Petersen (2009), "Financing innovation and growth: Cash flow, external equity, and the 1990s R\&D boom", The Journal of Finance, vol.64 (1), pp.151- 185.

Caldera-Sánchez A., de Serres A., Gori F., Hermansen M. and Röhn O. (2016), "Strengthening Economic Resilience: Insights from the Post-1970 Record of Severe Recessions and Financial Crises", OECD Economic Policy papers, No. 20, OECD Publishing, Paris.

Calvino, F., C. Criscuolo and C. Menon (2016), "No Country for Young Firms?: Start-up Dynamics and National Policies", OECD Science, Technology and Industry Policy Papers, No.29, OECD Publishing, Paris.

Cecchetti, S. and E. Kharroubi (2015), "Why does financial sector growth crowd out real economic growth?”, BIS Working Papers 490, Bank for International Settlements.

Chava S., A. Oettl, A. Subramanian and K. Subramanian (2013), "Banking Deregulation and Innovation", Journal of Financial Economics, 109 (3), pp.759-775.

Chavez S. and E. Ivan (2017), Credit information and firms' access to finance: evidence from an alternative measure of credit constraints, Washington, D.C.: World Bank Group.

Chen, P, L Karabarbounis, and B Neiman (2017), "The Global Rise of Corporate Savings", Journal of monetary economics, vol. 89(C), pp.1-19.

Claessens S. and L. Laeven (2005), "Financial Dependence, Banking Sector Competition, and Economic Growth", Policy Research Working Paper No. 3481. World Bank, Washington, DC.

Claessens S. and L. Laeven (2003), "Financial Development, Property Rights, and Growth", The Journal of Finance, vol.58(6), pp.2401-2436.

Cornaggia, J., Y. Mao, X. Tian, and B. Wolfe (2015), "Does banking competition affect innovation?" Journal of Financial Economics 115 (1), pp.189-209.

Corrado, C. A. and C. R. Hulten (2010), "How do you measure a "technological revolution"?" American Economic Review vol.100(2), pp.99-104.

Corrado, C. A., J. Haskel, M. Iommi, and C. Jona Lasinio (2012), "Intangible capital and growth in advanced economies: Measurement and comparative results", IZA Discussion Papers, No.6733, Institute for the Study of Labor (IZA). 
Corrado, C., Haskel, J., Jona-Lasinio, C., and M. Iommi (2016), "Intangible investment in the EU and US before and since the Great Recession and its contribution to productivity growth", EIB Working Papers No.2016/08, European Investment Bank (EIB).

Crouzet, Nicolas, and Janice Eberly (2018), "Understanding Weak Capital Investment: The Role of Market Concentration and Intangibles", document prepared for the 2018 Jackson Hole symposium. https://www.kansascityfed.org/ /media/files/publicat/sympos/2018/papersandhandouts/824180816cro uzeteberlyhandout.pdf?la=en

Dell'Ariccia G., Kadyrzhanova D., Minoiu C. and Ratnovski L. (2017), "Bank Lending in the Knowledge Economy", IMF working paper No.17/234, International Monetary Fund.

Denk, O. and G. Gomes (2017), "Financial re-regulation since the global crisis?: An index-based assessment", OECD Economics Department Working Papers, No. 1396, OECD Publishing, Paris.

Doidge, C., G. A. Karolyi, and R. M. Stulz (2017), "The U.S. listing gap", Journal of Financial Economics, vol.123(3), pp.464-487.

Duval, R. A., G. H. Hong, and Y. Timmer (2017). "Financial Frictions and the Great Productivity Slowdown", IMF Working Papers 17/129, International Monetary Fund.

Eisfeldt, A. L. and D. Papanikolaou (2014), "The value and ownership of intangible capital", American Economic Review, vol.104(5), pp.189-94.

Eisfeldt, A. L. and P. Dimitris (2013), "Organization capital and the cross section of expected returns". Journal of Finance, vol.68 (4), pp.1365-1406.

Falato, A., D. Kadyrzhanova, and J. Sim (2013), "Rising intangible capital, shrinking debt capacity, and the U.S. corporate savings glut", Finance and Economics Discussion Series, No.2013-67, Board of Governors of the Federal Reserve System (U.S.).

Fazzari S, Hubbard G. and B. Petersen (1998), Financing Constraints and Corporate Investment, Brookings Papers on Economic Activity, vol.1, pp.141-195

Fisman, R. and I. Love (2004), "Financial development and intersectoral allocation: A new approach", The Journal of Finance, vol.59 (6), pp.2785-2807.

Frenkel M and Mehrez G (2000), "Inflation and the Misallocation of Resources", Economic Inquiry, vol. 38 (4), pp.616-28.

Gilchrist S and P. Himmelberg (1995), "Evidence on the role of cash flow for investment", Journal of Monetary Economics, vol. 36(3), pp.541-572.

Gutierrez, G. and T. Philippon (2016), "Investment-less growth: An empirical investigation". NBER Working Paper No.22897, National Bureau of Economic Research, Inc.

Hall B and J. Lerner (2009), "The financing of R\&D and innovation”, NBER Working Papers, No.15325, National Bureau of Economic Research, Inc.

Hart, O. and J. Moore (1994), "A theory of debt based on the inalienability of human capital", The Quarterly Journal of Economics, vol.109(4), pp.841-879.

Haskel J. and S. Westlake (2018), Capitalism without Capital, Princeton, NJ: Princeton University Press.

Himmelberg, C.P. and B.C. Petersen (1994), "R\&D and internal finance: a panel study of small firms in high-tech industries", Review of Economics and Statistics, vol.76, pp.38-51.

Hsu, P.-H., X. Tian, and Y. Xu (2014), Financial development and innovation: Cross-country evidence. Journal of Financial Economics, vol.112(1), pp.116-135. 
King R.G. and R. Levine (1993), "Finance, entrepreneurship and growth", Journal of Monetary economics, vol.32(3), pp.513-542.

Kortum, S. and J. Lerner (2001), "Does venture capital spur innovation? In Entrepreneurial inputs and outcomes: New studies of entrepreneurship in the United States", in G.D. Libecap (ed.) Entrepreneurial inputs and outcomes: New studies of entrepreneurship in the United States (Advances in the Study of Entrepreneurship, Innovation \&amp; Economic Growth, Volume 13) Emerald Group Publishing Limited, pp.1 - 44.

Lev, B. and S. Radhakrishnan (2005), "The valuation of organization capital", In C. Corrado, J. Haltiwanger and D. Sichel, (ed.) Measuring capital in the new economy, pp.73-110. University of Chicago Press.

Marrocu E., R. Paci and M. Pontis (2011), "Intangible capital and firms' productivity", Industrial and Corporate Change, vol. 21(2), p.377-402.

McAfee A. and E. Brynjolfsson (2012), "Big Data: the management revolution", Harvard Business Review, vol.90 (10).

Myers, SC. (1977), "A note on the determinants of corporate debt capacity", Journal of Financial Economics, Vol.5. (2).

OECD (2013), Supporting Investment in Knowledge Capital, Growth and Innovation, OECD Publishing, Paris.

OECD (2018), Financing SMEs and Entrepreneurs 2018: An OECD Scoreboard, OECD Publishing, Paris.

Pagano, M. and G. Pica (2012), "Finance and employment". Economic Policy, vol.27(69), pp.5-55.

Peters, R.H. and L.A. Taylor (2017), "Intangible capital and the investment-Q relation", Journal of Financial Economics, vol.123(2), pp.251-272.

Porta, R. L., F. Lopez-de Silanes, A. Shleifer, and R.W. Vishny (1998), "Law and finance”, Journal of Political Economy, vol.106(6), pp.1113-1155.

Rajan, R. G. and L. Zingales (1998), "Financial dependence and growth", American Economic Review, vol.88(3), pp.559-586.

Stiglitz, J. E. and A. Weiss (1981), Credit rationing in markets with imperfect information, The American Economic Review, vol.71(3), pp.393-410.

Svirydzenka K, 2016. "Introducing a New Broad-based Index of Financial Development," IMF Working Papers, vol.16(5), International Monetary Fund.

World Bank (2018), Doing Business Report: reforming to create jobs, World Bank Publication. 


\section{Glossary and Variable Definitions}

\section{SECTOR-LEVEL VARIABLES}

\section{Industry classification}

Industries are defined based on NACE2 classification, which is closely related to ISIC4 rev2. We manually map historical Compustat SIC codes into this classification.

\section{Intangible asset intensity}

Intangible asset intensity is defined as the ratio between intangible assets and total assets (tangible and intangible), and it is a sector-level variable estimated using U.S firm-level data from Compustat. Intangible assets are estimated using the methodology described in Peters and Taylor (2017), first at firm-level and then at sector-level by capitalizing intangible-related expenses such as research and development (R\&D) and a fraction of selling, general and administrative expense (SG\&A). The R\&D expense, which includes a firm's spending to develop knowledge, patents, or software is considered an investment into knowledge capital. The SG\&A expense includes advertising to build brand capital, human capital, customer relationships and distribution systems, is considered an investment into organisational capital. We calculate several alternative variations for the intangible assets intensity. IntangIntens is a smoothed version (time-invariant) calculated first at the firm level as the sum of intangible assets over the sum of total assets over the 17-year period and then at the sector-level (median firm value). ${ }^{12}$ IntangIntens (knowledge) is calculated as the ratio between knowledge-based intangible assets and total assets while IntangIntens (organisation) as defined above. Source: Compustat.

\section{External financial dependence}

Financial dependence is calculated from Compustat U.S. firm-level data and defined as a sector-level characteristic (median firm value). We calculate several alternative variations of the financial dependence. FinDEP (standard RZ) is the original calculation as proposed by Rajan and Zingales (1998), using U.S. firm level data from Compustat that focuses on tangible investment only. It is the ratio between cumulative capital expenditures minus cumulative cash flow from operations and cumulative capital expenditures calculated at the firm level. FinDEP ( + R\&D investment) includes R\&D investments some of which are already marketable, such as patents, brands and licenses. FinDEP $(+$ other intangible investment) incorporates all intangible capital investment, both in the numerator and denominator. It leads to a rescaled measure of financial dependence that includes $R \& D$, as SG\&A expenses are already included in the calculation of operating cash flows. Source: Compustat.

\section{Equity financial dependence}

External equity dependence are defined at sector-level from Compustat U.S. firm-level data and defined as a sector-level characteristics (median firm level values). EquityDEP is defined as the ratio of the net amount of equity issues to capital investment (including R\&D). Source: Compustat.

\footnotetext{
${ }^{12}$ The external capital dependence calculated by Rajan and Zingales (1998) is calculated in a similar manner, albeit using a different underlying variable.
} 


\section{COUNTRY-SECTOR VARIABLES}

\section{Labour productivity, R\&D Expenses and Capital stock}

Labour productivity is calculated as value added per employee and capital stock are extracted from OECD-STAN database. Business Expenditure on R\&D data are extracted from MSTI-OECD database.

\section{COUNTRY-LEVEL VARIABLES}

\section{Financial development}

Country level financial development is calculated either as a time-invariant measure (initial sample values) or time-varying (IMF indices). The time-invariant measures are Domestic Credit and Market Capitalisation, both calculated as a percentage of GDP. The time-varying measures are calculated by the IMF staff (Svirydzenka, 2016): the global index (IMF Global Fin Index), the overall development of financial markets (IMF Fin Markets Dev Index) and the overall development of financial institutions (IMF Fin Inst Index). The last two indices are further decomposed based on market depth, access and efficiency. Source: These series are available on the IMF website.

\section{Venture capital}

Venture capital relative to GDP (a subset of private equity) refers to equity investment made in early, maturity and buyout stage of business developed by enterprises not quoted on the stock market. The venture capital investments indicators are compiled based on the data collected by the INVEST Europe (formerly named European Private Equity \& Venture Capital Association EVCA) survey of all private equity and venture capital companies. Private equity can be further used to expand working capital, to make acquisitions, to strengthen a company's balance sheet and for buyouts. Due to a collection break in 2006, granular data is only available before 2006. Source: EUROSTAT.

\section{Banking concentration}

Bank concentration is defined as the assets of three largest commercial banks as a share of total commercial banking assets. Total assets include total earning assets, cash and due from banks, foreclosed real estate, fixed assets, goodwill, other intangibles, current tax assets, deferred tax assets, discontinued operations and other assets. Raw data are from Bankscope and are only reported if number of banks in Bankscope is 3 or more. Series are available for the period 1997-2014. Source: World Bank Global Financial Development database.

\section{Legal and creditor rights}

Enforcing Contracts variable captures the time and cost for resolving a commercial dispute through a local first-instance court and the quality of judicial processes index. It evaluates whether countries have adopted a series of good practices that promote quality and efficiency in the court system. Resolving Insolvency captures to cost and outcome of insolvency proceedings involving domestic entities as well as the strength of the legal framework applicable to judicial liquidation and re-organisation proceedings. Depth of credit information index measures rules and practices affecting the coverage, scope and accessibility of credit information available through either a credit bureau or a credit registry. Source: World Bank, Doing Business Database.13

\footnotetext{
${ }^{13}$ http://www.doingbusiness.org/methodology
} 


\section{Annex A. Descriptive statistics and robustness checks}

Table A.1. Intangible Intensity by sector

\begin{tabular}{|c|c|c|c|c|}
\hline & & $(1)$ & (2) & (3) \\
\hline Sector & Sector name & $\begin{array}{l}\text { Intangible Capital } \\
\text { Intensity (smooth) }\end{array}$ & $\begin{array}{c}\text { Intangible Capital } \\
\text { Intensity (Knowledge- } \\
\text { based) }\end{array}$ & $\begin{array}{c}\text { Intangible Capital } \\
\text { Intensity } \\
\text { (Organisation-based) }\end{array}$ \\
\hline D01T03 & Agriculture & 0.28 & 0.00 & 0.12 \\
\hline D05T09 & Mining & 0.06 & 0.00 & 0.03 \\
\hline D10T12 & Food & 0.42 & 0.00 & 0.25 \\
\hline D13 & Textiles & 0.31 & 0.00 & 0.21 \\
\hline D14 & Wearing apparel & 0.63 & 0.00 & 0.52 \\
\hline D15 & Leather & 0.64 & 0.00 & 0.58 \\
\hline D16 & Wood & 0.30 & 0.00 & 0.14 \\
\hline D17 & Paper & 0.21 & 0.00 & 0.09 \\
\hline D18 & Printing & 0.37 & 0.00 & 0.25 \\
\hline D19 & Coke and petroleum & 0.31 & 0.03 & 0.13 \\
\hline D21 & Pharmaceutical & 0.81 & 0.60 & 0.05 \\
\hline D22 & Rubber and plastic & 0.36 & 0.03 & 0.22 \\
\hline D23 & Mineral (non-metallic) & 0.24 & 0.00 & 0.13 \\
\hline D24 & Basic metals & 0.20 & 0.00 & 0.10 \\
\hline D25 & Fabricated metal & 0.42 & 0.02 & 0.23 \\
\hline D26 & Computer eq. & 0.63 & 0.25 & 0.21 \\
\hline D27 & Electrical eq. & 0.63 & 0.24 & 0.25 \\
\hline D28 & Machinery and eq. & 0.54 & 0.11 & 0.24 \\
\hline $\mathrm{D} 29$ & Motor vehicles & 0.40 & 0.05 & 0.17 \\
\hline D30 & Misc transport eq. & 0.46 & 0.05 & 0.14 \\
\hline D31T33 & Furniture & 0.67 & 0.18 & 0.29 \\
\hline D41T43 & Construction & 0.38 & 0.00 & 0.22 \\
\hline D45T47 & Trade & 0.56 & 0.00 & 0.45 \\
\hline D49T53 & Transport & 0.10 & 0.00 & 0.03 \\
\hline D55T56 & Hotels and rest & 0.39 & 0.00 & 0.20 \\
\hline D58 & Publishing & 0.65 & 0.00 & 0.26 \\
\hline D59T60 & Broadcasting & 0.23 & 0.00 & 0.12 \\
\hline D61 & Telecom & 0.37 & 0.00 & 0.07 \\
\hline D62TD63 & Programming and information & 0.78 & 0.30 & 0.31 \\
\hline D69T82 & Prof. serv. & 0.62 & 0.00 & 0.24 \\
\hline
\end{tabular}

Note: Intangible asset intensity is defined as the median sector-level value of the ratio between intangible assets and total assets. It is calculated for all U.S. listed firms in Compustat from 1990-2006. The knowledge- and organisational-based measures are described in Box 1. The two components of intangible intensity may not add up because sector median-firm values could be different across the three dimensions.

Source: Compustat. 
Table A.2. Financial Dependence measures by sector

\begin{tabular}{|c|c|c|c|c|}
\hline & $\begin{array}{c}\text { FinDEP } \\
\text { (RZ) }\end{array}$ & $\begin{array}{l}\text { FinDEP } \\
(+R \& D)\end{array}$ & $\begin{array}{c}\text { FinDEP } \\
\text { (+Intang) }\end{array}$ & $\begin{array}{c}\text { Equity FinDEP } \\
(+\mathrm{R} \& \mathrm{D})\end{array}$ \\
\hline Agriculture & -0.326 & -0.048 & -0.024 & 0.050 \\
\hline Mining & 0.463 & 0.463 & 0.433 & 0.294 \\
\hline Food & -0.504 & -0.434 & -0.163 & 0.008 \\
\hline Textiles & -0.210 & -0.101 & -0.048 & 0.008 \\
\hline Wearing apparel & -0.654 & -0.647 & -0.175 & 0.107 \\
\hline Leather & -0.913 & -0.840 & -0.133 & 0.031 \\
\hline Wood & -0.107 & -0.107 & -0.049 & 0.018 \\
\hline Paper & -0.281 & -0.197 & -0.159 & 0.000 \\
\hline Printing & -0.674 & -0.667 & -0.203 & 0.021 \\
\hline Coke and petroleum & -0.431 & -0.189 & -0.104 & 0.000 \\
\hline Pharmaceutical & 3.030 & 1.368 & 1.288 & 0.370 \\
\hline Rubber and plastic & -0.276 & -0.038 & -0.024 & 0.000 \\
\hline Mineral (non-metallic) & -0.320 & -0.232 & -0.154 & 0.000 \\
\hline Basic metals & -0.127 & -0.084 & -0.048 & 0.069 \\
\hline Fabricated metal & -0.531 & -0.273 & -0.125 & 0.000 \\
\hline Computer eq. & -0.016 & 0.566 & 0.406 & 0.123 \\
\hline Electrical eq. & -0.075 & 0.520 & 0.328 & 0.125 \\
\hline Machinery and eq. & -0.351 & 0.239 & 0.110 & 0.068 \\
\hline Motor vehicles & -0.095 & 0.233 & 0.135 & 0.031 \\
\hline Misc transport eq. & -0.828 & -0.096 & -0.070 & 0.015 \\
\hline Furniture & -0.360 & 0.396 & 0.213 & 0.106 \\
\hline Construction & 0.336 & 0.370 & 0.205 & 0.102 \\
\hline Trade & -0.147 & -0.133 & -0.035 & 0.027 \\
\hline Transport & 0.049 & 0.094 & 0.049 & 0.068 \\
\hline Hotels and rest & 0.161 & 0.163 & 0.073 & 0.167 \\
\hline Publishing & -1.532 & -1.458 & -0.424 & 0.000 \\
\hline Broadcasting & 0.187 & 0.187 & 0.156 & 0.355 \\
\hline Telecom & 0.148 & 0.170 & 0.130 & 0.243 \\
\hline Programming and information & 0.057 & 0.717 & 0.447 & 0.266 \\
\hline Prof. serv. & -0.264 & -0.184 & -0.066 & 0.217 \\
\hline
\end{tabular}

Note: FinDEP is the standard external financial dependence as calculated by Rajan and Zingales (1998), extended over 1990-2006. FinDEP (+R\&D) is the external financial dependence that includes R\&D expenditures. FinDEP (+intangibles) is the external financial dependence that includes all intangible investment. It is defined as the ratio between cumulative capital expenditures (including R\&D) minus cumulative cash flow from operations and cumulative capital expenditures calculated at firm level from 1980 to 2006. For more details see Box 1. EquityDEP (+R\&D) is defined as the ratio of the net amount of equity issues (net amount of debt issues) to capital investment (including R\&D). The sample includes all U.S listed firms in Compustat, excluding financial, utilities and public service.

Source: Compustat 
Table A.3. Summary statistics

\begin{tabular}{|c|c|c|c|c|c|c|}
\hline & $(1)$ & $(2)$ & $(3)$ & $(4)$ & $(5)$ & (6) \\
\hline & $\mathrm{N}$ & mean & p50 & sd & $\min$ & $\max$ \\
\hline \multicolumn{7}{|c|}{ Country-Year Variables } \\
\hline Market cap (initial) to GDP & 757 & 0.028 & 0.022 & 0.023 & 0.000 & 0.094 \\
\hline Domestic credit (initial) to GDP & 757 & 0.068 & 0.062 & 0.039 & 0.007 & 0.192 \\
\hline IMF Global Fin Index & 546 & 0.665 & 0.687 & 0.173 & 0.128 & 1.000 \\
\hline IMF Fin Markets Dev Index & 546 & 0.583 & 0.604 & 0.228 & 0.048 & 1.000 \\
\hline IMF Fin Markets Access Index & 546 & 0.739 & 0.776 & 0.160 & 0.199 & 1.000 \\
\hline Venture Capital (to GDP) & 197 & 0.034 & 0.027 & 0.036 & 0.000 & 0.260 \\
\hline Private Equity (to GDP) & 391 & 0.214 & 0.142 & 0.251 & 0.000 & 2.100 \\
\hline Labour regulation & 385 & 2.226 & 1.270 & 0.671 & 1.095 & 4.583 \\
\hline GDP growth & 469 & 2.451 & -0.853 & 3.362 & -14.810 & 25.560 \\
\hline Inflation & 469 & 81.9 & 63.2 & 14.6 & 31.9 & 104.1 \\
\hline \multicolumn{7}{|c|}{ Country-Sector-Year Variables } \\
\hline LP (log change) & 7,221 & 0.017 & 0.016 & 0.137 & -3.962 & 1.880 \\
\hline Capital stock (log change) & 7,221 & 0.016 & 0.011 & 0.053 & -0.614 & 1.045 \\
\hline Capital stock (log level) & 7,221 & 9.960 & 9.652 & 2.706 & 3.573 & 19.720 \\
\hline R\&D (log change) & 3,426 & 0.036 & 0.025 & 0.383 & -6.286 & 4.383 \\
\hline \multicolumn{7}{|c|}{ Country-Year Policy Variables } \\
\hline Financial reform Index & 431 & 0.90 & 0.95 & 0.11 & 0.44 & 1.00 \\
\hline Interest Rate Liberalization & 440 & 0.98 & 1.00 & 0.09 & 0.00 & 1.00 \\
\hline Bank sector entry & 440 & 0.98 & 1.00 & 0.09 & 0.33 & 1.00 \\
\hline Privatization & 440 & 0.74 & 1.00 & 0.34 & 0.00 & 1.00 \\
\hline Securities market policies & 440 & 0.98 & 1.00 & 0.08 & 0.33 & 1.00 \\
\hline Enforcement contracts & 260 & 72.3 & 75.1 & 10.1 & 34.7 & 86.0 \\
\hline Depth Credit Info & 218 & 76.7 & 83.3 & 21.1 & 0.0 & 100.0 \\
\hline Resolve Insolvency & 277 & 77.4 & 86.4 & 20.2 & 36.6 & 100.0 \\
\hline Bank concentration & 324 & 81.7 & 86.4 & 16.4 & 39.0 & 100.0 \\
\hline
\end{tabular}

Note: All variables are described in Table 1 and Glossary.

Source: IMF, Eurostat, World Bank 
Table A.4. Correlation matrix

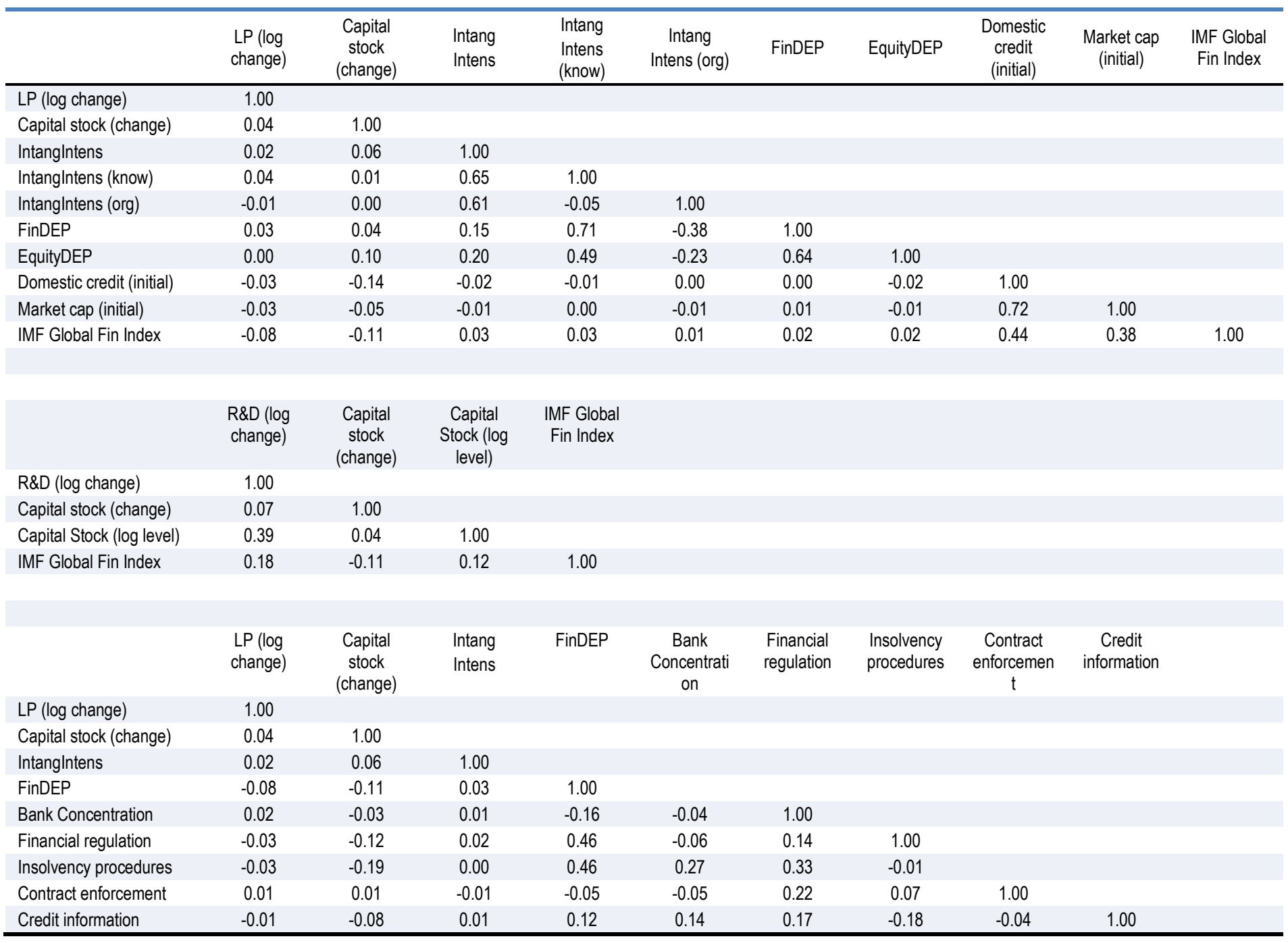

Note: Intangible asset intensity is defined as the median sector-level value of the ratio between intangible assets and total assets. FinDEP is the external financial dependence that includes R\&D expenditures. It is defined as the ratio between cumulative capital expenditures (including $R \& D$ ) minus cumulative cash flow from operations and cumulative capital expenditures. Both sector-level variables are calculated at firm level from 1980 to 2006. For more details see Box 1. Policy variables (outcome or regulatory) are described in Table 1.

Source: IMF, Eurostat, World Bank, Compustat 
Table A.5. Components of the financial development index

\begin{tabular}{|c|c|c|c|}
\hline Dependent variable: Labour Productivity Growth & (1) & $(2)$ & (3) \\
\hline FINDEV measures & IMF Global Fin Index & $\begin{array}{l}\text { IMF Fin Markets Dev } \\
\text { Index }\end{array}$ & $\begin{array}{l}\text { IMF Fin Markets } \\
\text { Access Index }\end{array}$ \\
\hline \multirow[t]{2}{*}{ Labour Productivity log (initial) } & $-0.021^{\star \star *}$ & $-0.022^{\star \star *}$ & $-0.022^{* * *}$ \\
\hline & $(0.000)$ & $(0.000)$ & $(0.000)$ \\
\hline \multirow[t]{2}{*}{ FinDEV * IntangIntens } & $0.076^{* *}$ & $0.040^{* *}$ & $0.029^{*}$ \\
\hline & $(0.012)$ & $(0.038)$ & $(0.095)$ \\
\hline \multirow[t]{2}{*}{ Capital stock log (change) } & 0.079 & 0.079 & 0.077 \\
\hline & $(0.125)$ & $(0.126)$ & $(0.133)$ \\
\hline Observations & 7,221 & 7,221 & 7,221 \\
\hline R-squared & 0.143 & 0.143 & 0.143 \\
\hline Country-Year FE & YES & YES & YES \\
\hline Sector FE & YES & YES & YES \\
\hline
\end{tabular}

Note: The dependent variable is labour productivity growth. All regressions include sector and country-year fixed effects (FE). Robust standard errors are clustered at the industry level. *,**, *** denote statistical significance at the $10 \%, 5 \%$ and $1 \%$ levels.

Table A.6. Robustness check: including additional country-year variables

\begin{tabular}{lccccc}
\hline $\begin{array}{l}\text { Dependent variable: Labour Productivity } \\
\text { Growth }\end{array}$ & $(1)$ & $(2)$ & $(3)$ & $(4)$ & $(5)$ \\
\hline FINDEV measure & $\begin{array}{c}\text { IMF Global Fin } \\
\text { Index }\end{array}$ & $\begin{array}{c}\text { IMF Global Fin } \\
\text { Index }\end{array}$ & $\begin{array}{c}\text { IMF Global Fin } \\
\text { Index }\end{array}$ & $\begin{array}{c}\text { IMF Global Fin } \\
\text { Index }\end{array}$ & $\begin{array}{c}\text { IMF Global Fin } \\
\text { Index }\end{array}$ \\
\hline Initial Labour Productivity & $-0.021^{* * *}$ & $-0.021^{* * *}$ & $-0.024^{* * *}$ & $-0.021^{* * *}$ & $-0.024^{* * *}$ \\
& $(0.000)$ & $(0.001)$ & $(0.000)$ & $(0.001)$ & $(0.000)$ \\
Change Capital Stock & $0.080^{* *}$ & $0.080^{* *}$ & 0.067 & $0.080^{* *}$ & 0.069 \\
& $(0.025)$ & $(0.026)$ & $(0.122)$ & $(0.024)$ & $(0.114)$ \\
FinDEV * IntangIntens & $0.072^{* *}$ & $0.054^{* * *}$ & $0.117^{* *}$ & $0.055^{* * *}$ & $0.096^{*}$ \\
& $(0.012)$ & $(0.002)$ & $(0.024)$ & $(0.003)$ & $(0.077)$ \\
GDP growth * IntangIntens & -0.002 & & & -0.001 & -0.004 \\
& $(0.728)$ & & & $(0.870)$ & $(0.436)$ \\
Inflation * IntangIntens & & 0.001 & & 0.000 & 0.000 \\
& & $(0.340)$ & & $(0.449)$ & $(0.775)$ \\
Labour regulation * IntangIntens & & & -0.005 & & -0.008 \\
& & & $(0.445)$ & & $(0.141)$ \\
Observations & & & & \\
R-squared & 7,221 & 7,221 & 6,372 & 7,221 & 6,372 \\
Country-year FE & 0.144 & 0.144 & 0.147 & 0.144 & 0.147 \\
Sector FE & YES & YES & YES & YES & YES \\
\hline
\end{tabular}

Note: The dependent variable is labour productivity growth. FinDEV is the IMF Global Fin Index. All regressions include sector and country-year fixed effects. Robust standard errors are clustered at the industry level. *,**,*** denote statistical significance at the $10 \%, 5 \%$ and $1 \%$ levels. 
Table A.7. Robustness check: including alternative fixed effects and clustering

\begin{tabular}{|c|c|c|c|c|c|c|}
\hline Dependent Variable: Labour Productivity (Level) & $(1)$ & $(2)$ & $(3)$ & $(4)$ & $(5)$ & $(6)$ \\
\hline FINDEV & $\begin{array}{l}\text { IMF Global Fin } \\
\text { Index }\end{array}$ & $\begin{array}{l}\text { IMF Global Fin } \\
\text { Index }\end{array}$ & $\begin{array}{c}\text { Domestic } \\
\text { credit }\end{array}$ & $\begin{array}{l}\text { Domestic } \\
\text { credit }\end{array}$ & $\begin{array}{c}\text { Market } \\
\text { cap }\end{array}$ & $\begin{array}{c}\text { Market } \\
\text { cap }\end{array}$ \\
\hline \multirow[t]{2}{*}{ FinDEV*IntangIntens } & $1.421^{\star \star *}$ & $1.242^{* * *}$ & $0.004^{* * *}$ & 0.001 & $0.002^{* * *}$ & $0.001^{*}$ \\
\hline & $(0.000)$ & $(0.000)$ & $(0.000)$ & $(0.493)$ & $(0.005)$ & $(0.076)$ \\
\hline \multirow[t]{2}{*}{ Capital Stock Change } & & -0.092 & & -0.116 & & -0.203 \\
\hline & & $(0.535)$ & & $(0.471)$ & & $(0.201)$ \\
\hline Observations & 10,703 & 6,171 & 9,513 & 5,722 & 9,718 & 5,850 \\
\hline R-squared & 0.983 & 0.985 & 0.984 & 0.985 & 0.985 & 0.985 \\
\hline Country-Year \& Country-Sector FE & YES & YES & YES & YES & YES & YES \\
\hline Country-Year Sector-Year Cluster & YES & YES & YES & YES & YES & YES \\
\hline
\end{tabular}

Note: The dependent variable is labour productivity. $*, * *, * * *$ denote statistical significance at the $10 \%, 5 \%$ and $1 \%$ levels. 


\section{Figure A.1. External Financial Dependence and Intangible Assets Intensity over time}
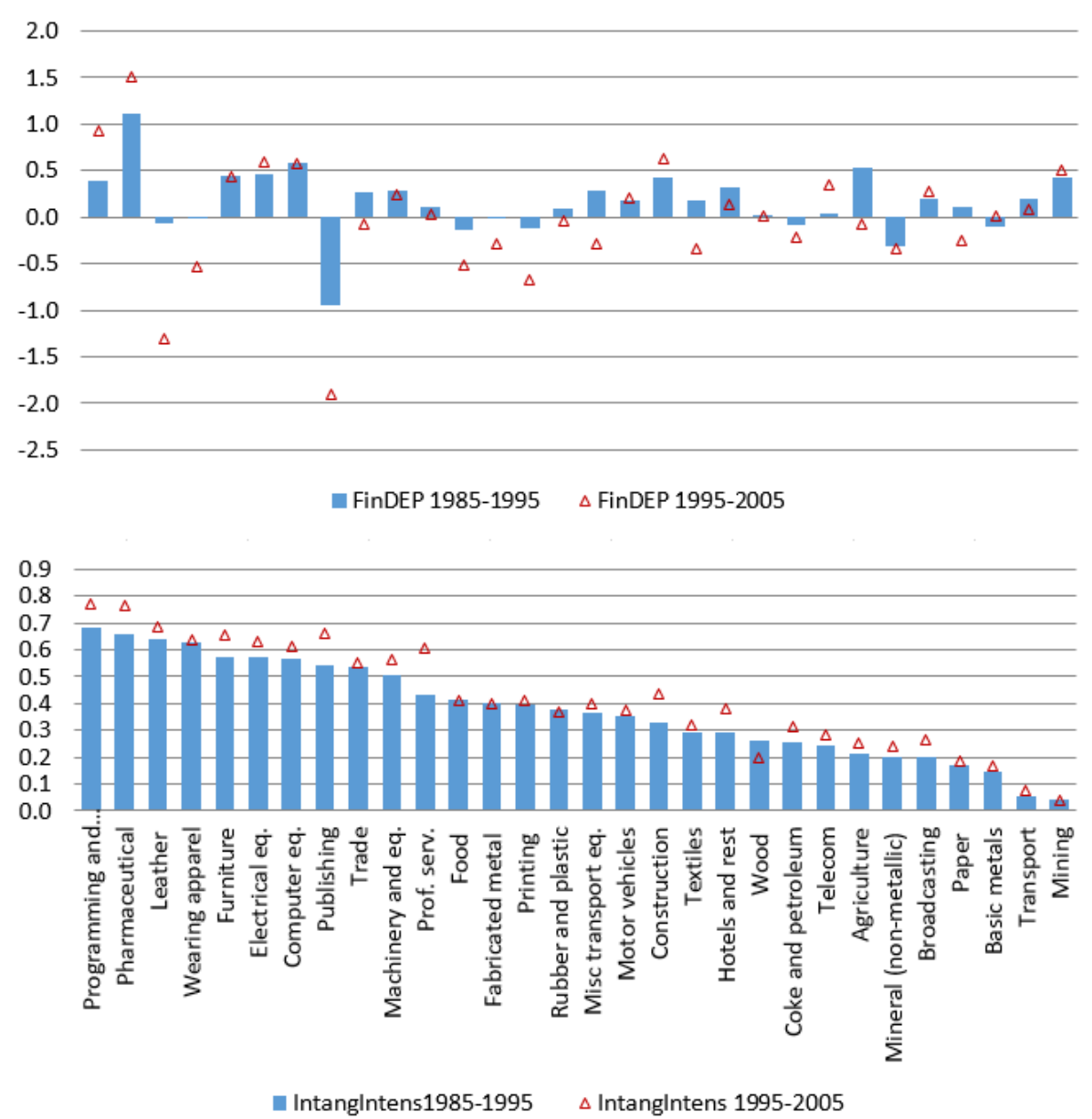

Note: External financial dependence is defined as the ratio between cumulative capital expenditures (including R\&D) minus cumulative cash flow from operations and cumulative capital expenditures calculated at firm level over a 10-year rolling window from 1980 to 2006. The sample includes all U.S firms, excluding financial, utilities and public service. Negative value indicates reliance on external finance.

Source: Compustat 
Figure A.2. Marginal Effect of Financial Development based on Equity Financial Dependence
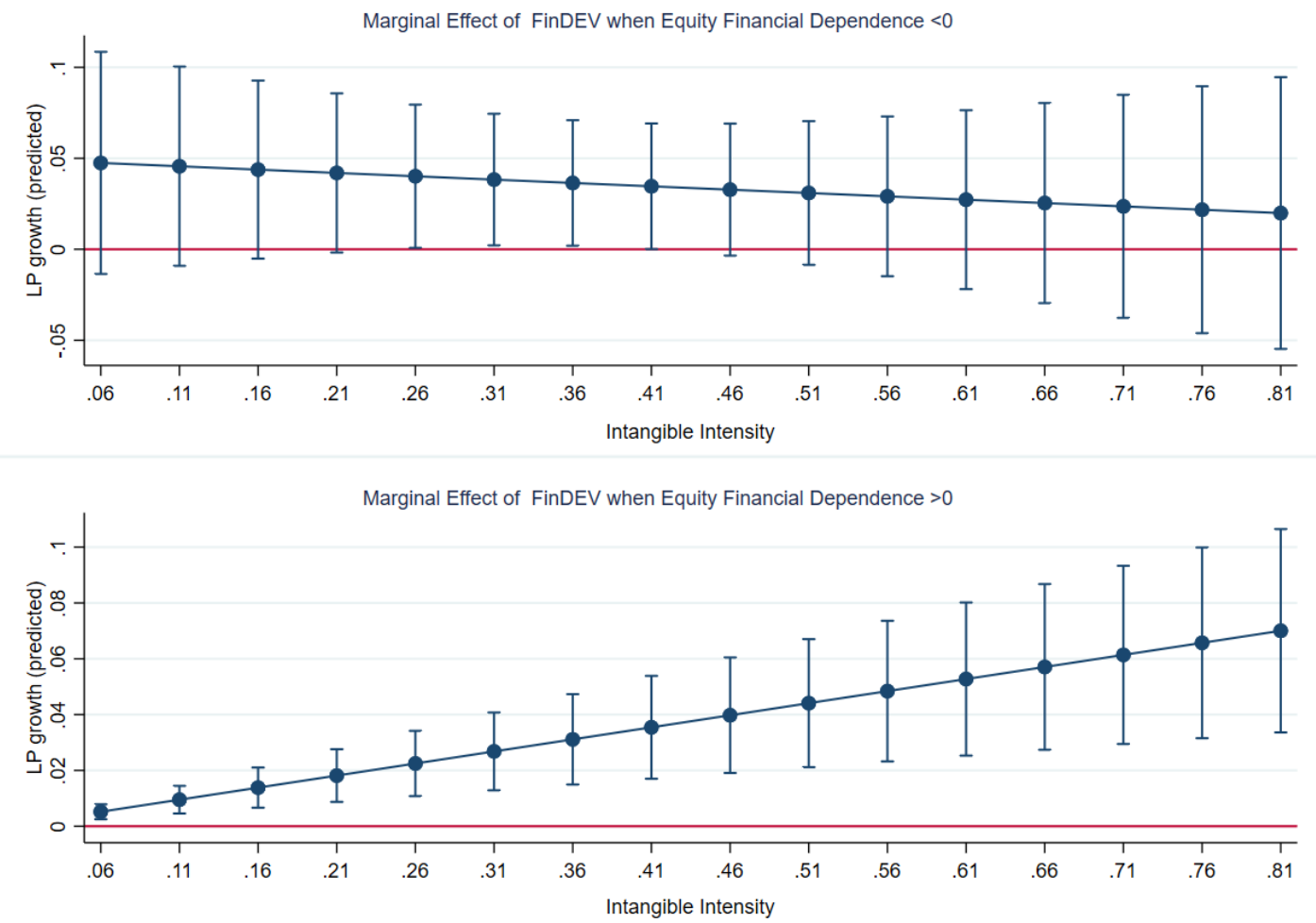

Note: The figure shows the marginal effects (equation 3) separately for positive equity financial dependence (on top) and zero equity financial dependence (on bottom). Marginal effects are estimated using the regression presented in Table 4, column 1. Vertical lines report confidence intervals and show non-significant effects when the value zero is within the interval.

Source: OECD's calculations. 